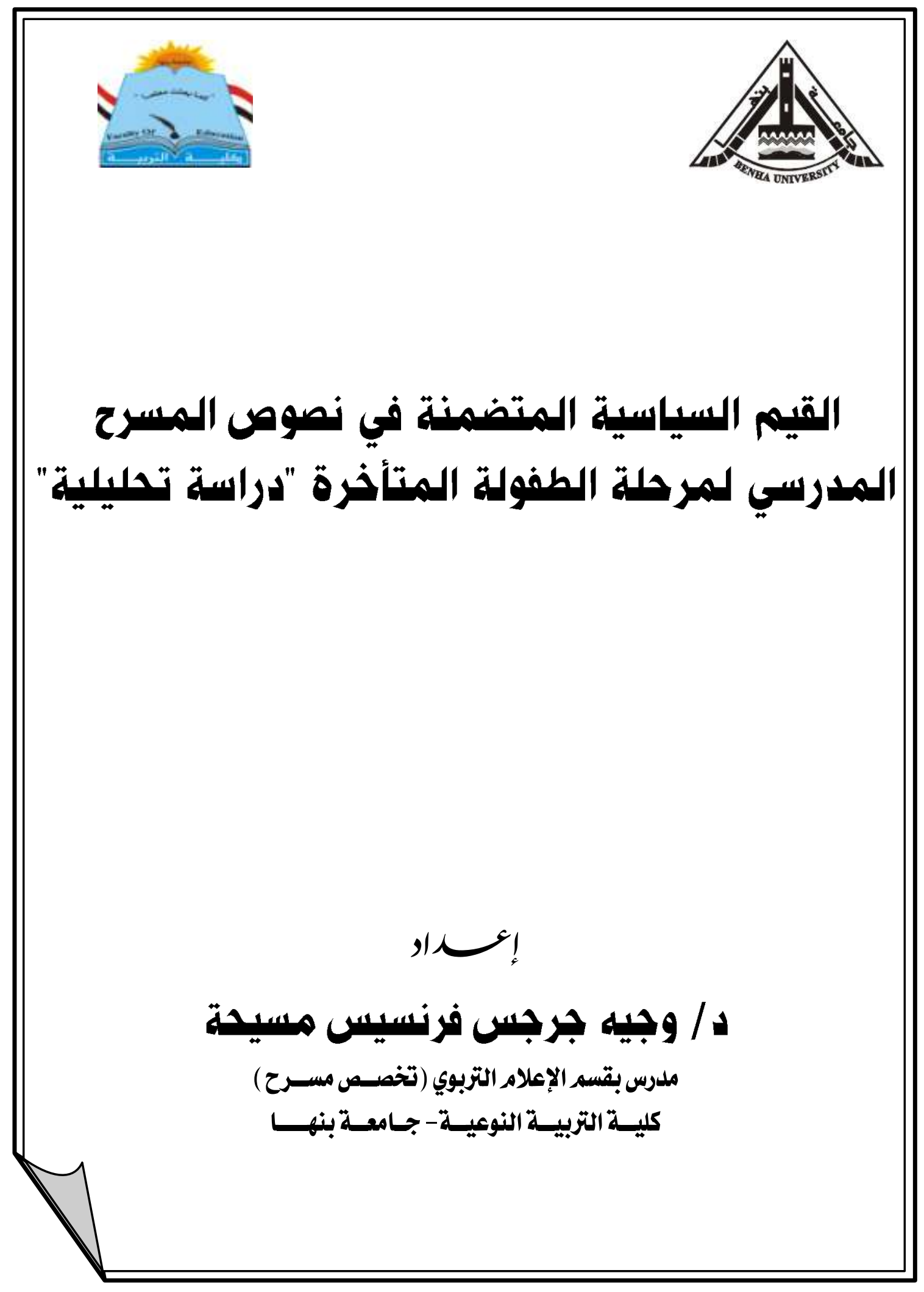




\title{
القيم السياسية المتضمنة في نصوص المسرح المدرسي لمرحلة الطفولة المتأخرة "دراسة تحليلية"
}

\author{
إ
}

\section{د/ وجيه جرجس فرنسيس مسيحتة}

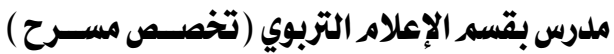

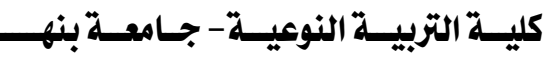

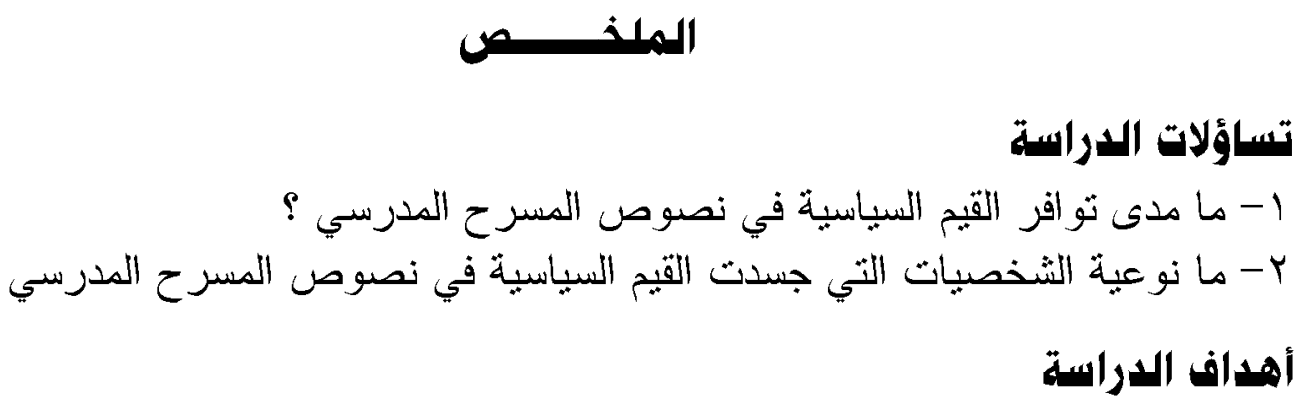

1- تحديد القبم السياسية المناسبة لتلاميذ مرحلة الطفولة المتأخرة r- التوصل إلى مجموعة من التوصيات و المقترحات التي توجه إلى القائمبن على المسرح أهمية الدراسة

1- تقديم ثائمة بالقيم السياسية المثضمنة في نصوص المسرح المدرسي المقدمسة لتلاميــذ مرحلة الطفولة المتأخرة. r- أهمية المرحلة العمرية الموجه إليها نصوص المبوص المسرح المدرسي حبث يكون الثلاميذ في

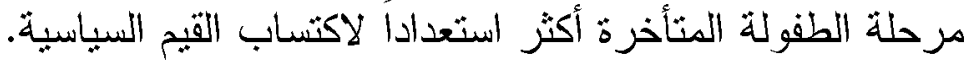

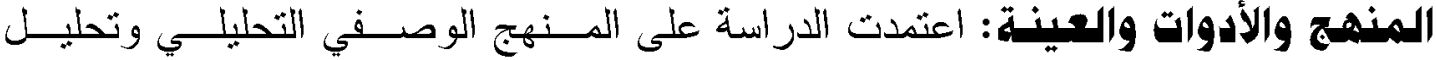

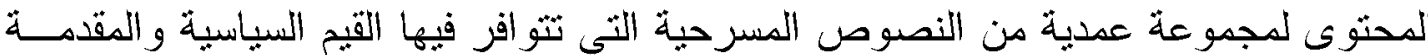
التلاميذ مرحلة الطفولة المنأخرة. النتائج العامة للدراسة: ظهرت بعض القيم السياسية المقدمة لتلاميذ مرحلة الطفولة المنــأخرة

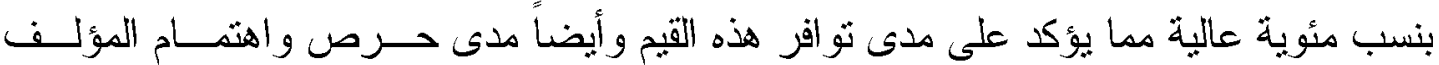

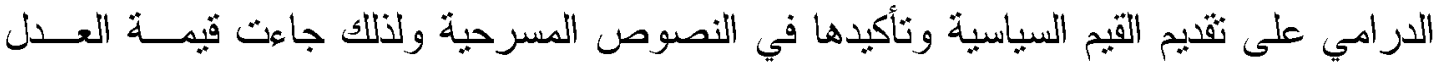

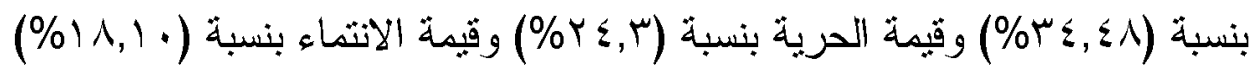

الكلمات المفتاهية: القيم السياسية Political values الدسرح الدرسي 


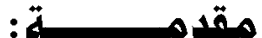

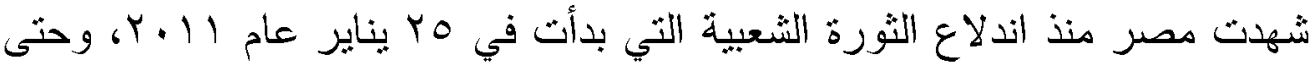
الآن العديد من الأحداث السياسية والاقتصادية والاجنماعية والثقافية، أدث إلى إحداث العديد

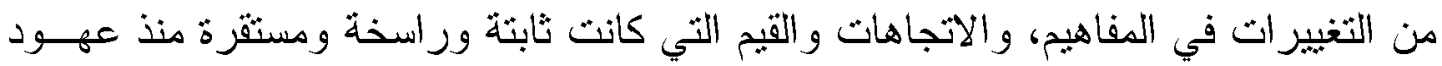
طويلة، مما انعكس بدوره على أطفالنا من حيث درجة الاتتماء والقيم وتعزيز الهوية الوطنية.

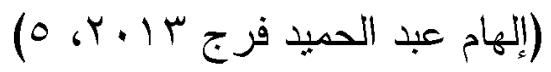

ونتيجة الثورة المعلوماتية الهائلة، والفضائيات، وشُبكة المعلومات وما تقدمه من مواد

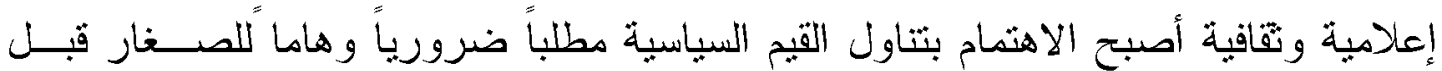

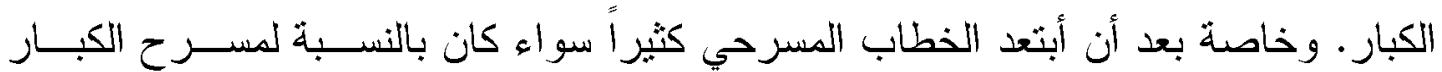

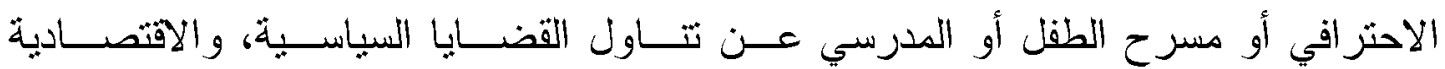

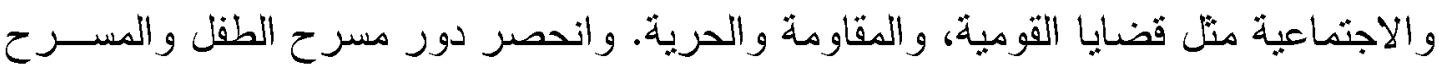

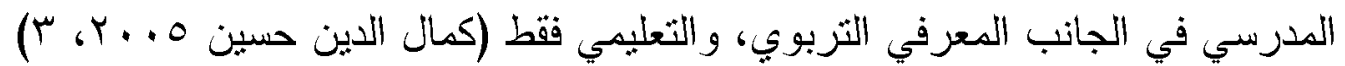

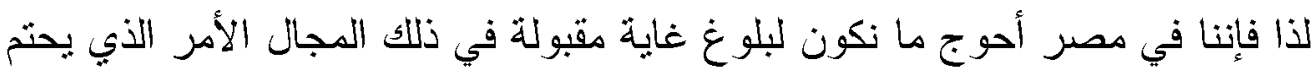

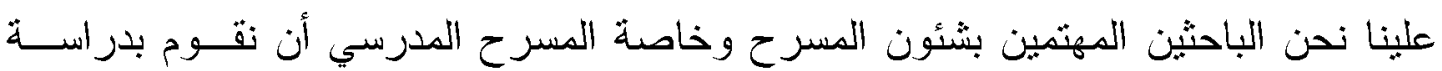

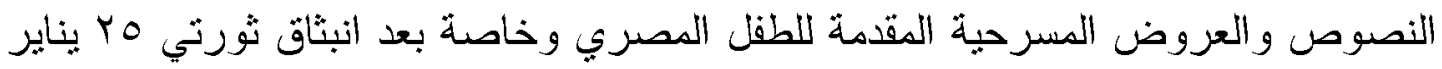

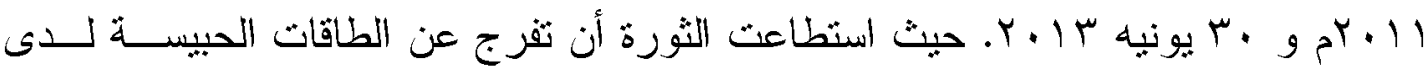

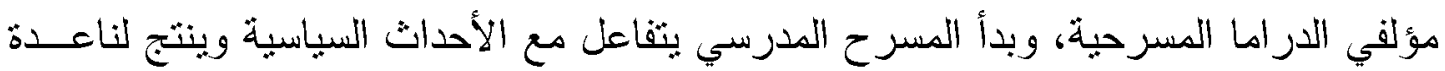

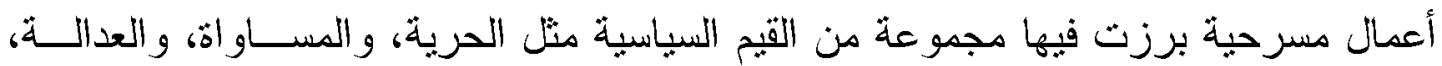

$$
\text { و السلام، و المشاركة و الايمقر اطبة و غير ها. }
$$

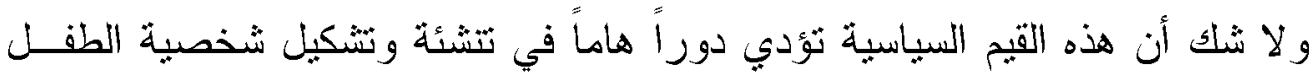

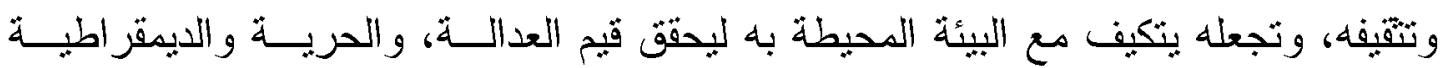

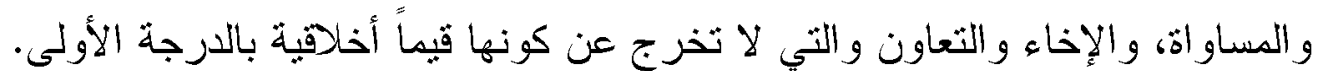

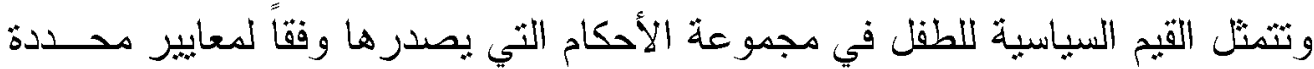

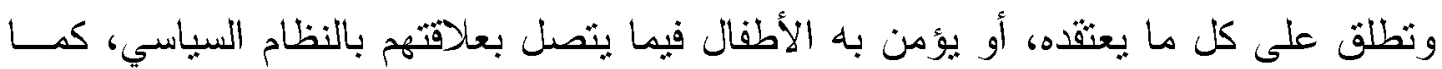

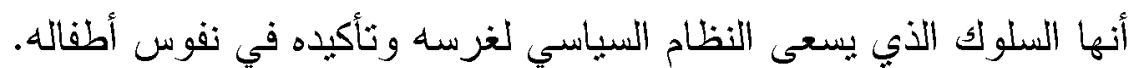

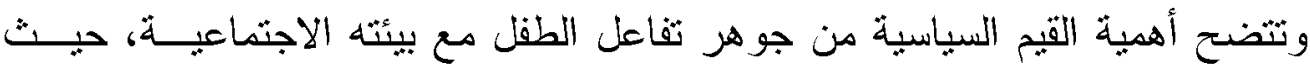
تعتبر جزءاً هاماً في الإطار المرجعي للسلوك في الحباة العامة، وفي مجالاتها المختلفة دينياً،

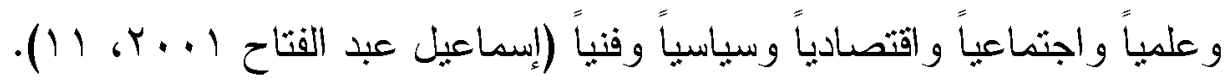


وتتأكد أهية القيم السياسية للطقل من كونها نتشأ على احترام كرامته، كما في قيمة الحرية،

و المساو اة، والتضامن، كذلك نساعد على احثرام حقوق الإنسان (8) Halla Halm)

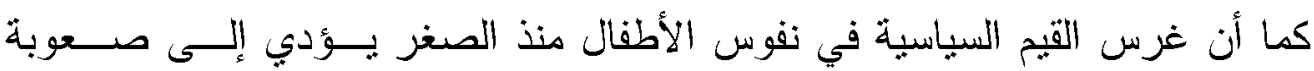

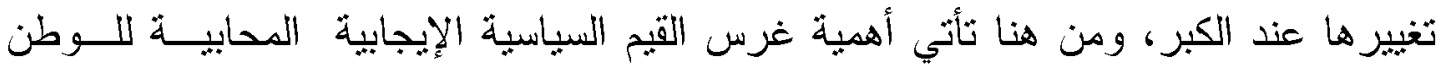

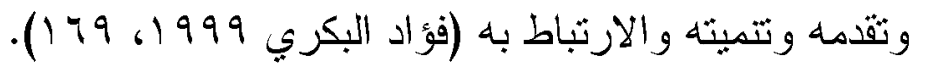

وتأسيساً على ما تقدم بمكن إيجاز أهمية القيم السياسية للطقل في النئ النقاط الآتية:

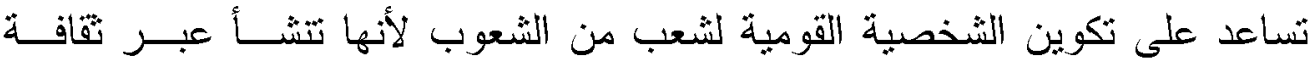
المجتمع وتتشئته الاجتماعبة. ميخذ كأساس للحكم على سلوك الآخرين.

تساعد على نحديد سلوك الطفل وتوجهاته في المجتمع الذي بعيش فيه. تساعد على تحديد سلوك الجماعة من خلال التفاعل الاجتماعي.

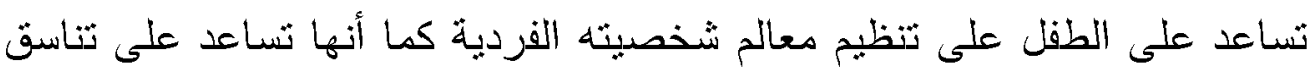

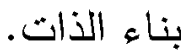

$$
\text { تولد لدى الطفل الثنعور بالصواب و الخطأ. }
$$

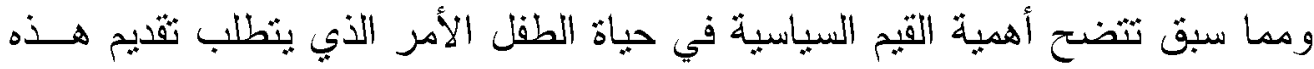

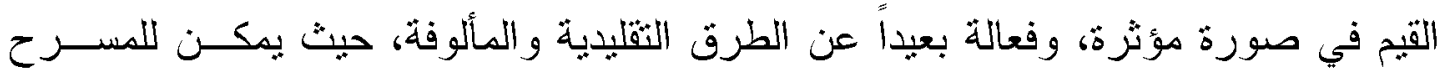

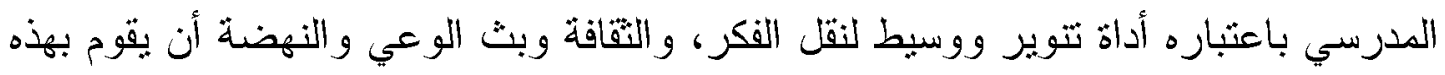

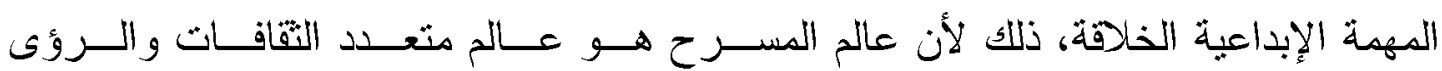

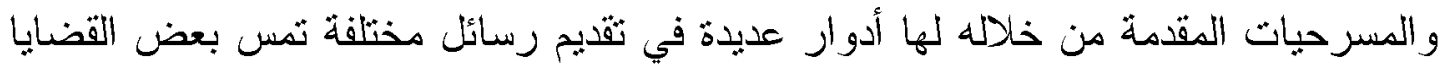

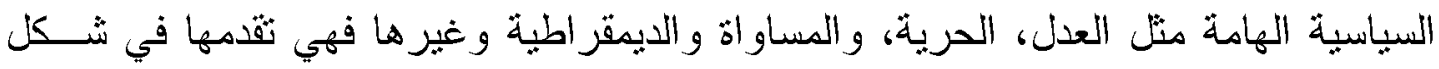

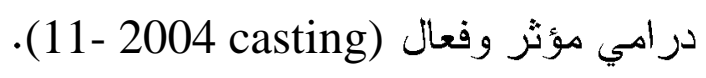
يمكن للأطفال أن يكتسبوا القيم السياسية من خلال موضو عات المســرحيات، ومــن فئن

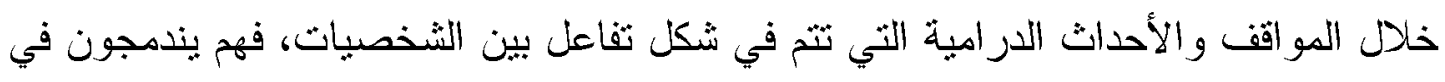

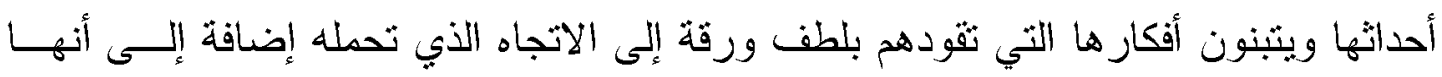

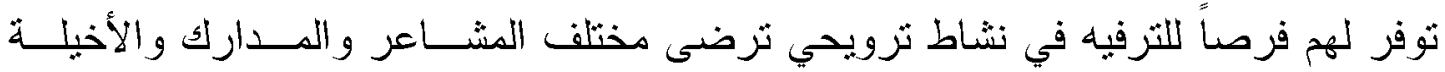

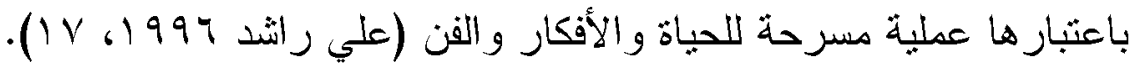


1 - جيرفيس ماري 2001 Germais marie بعنوان كيــف يظهـر طـلاب المدرســة الإعدادية قرارات القيم من خلال عملية الدراما.

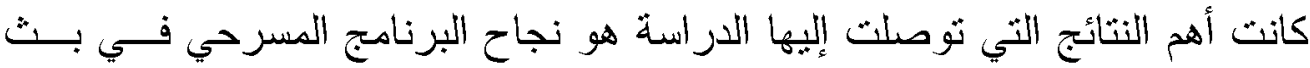

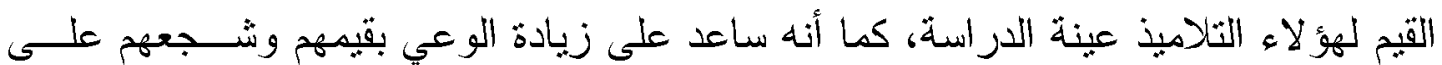

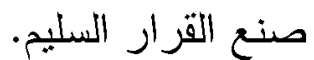

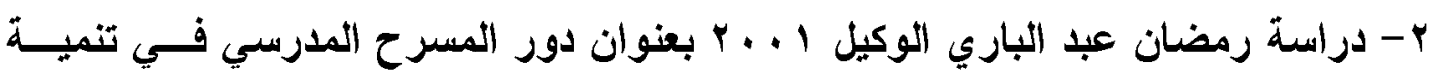
الاتتماء للوطن.

كانت أهم النتائج الني نوصلت إليها الدراسة هو ضعف الثعور بالمســولية اتجــاه

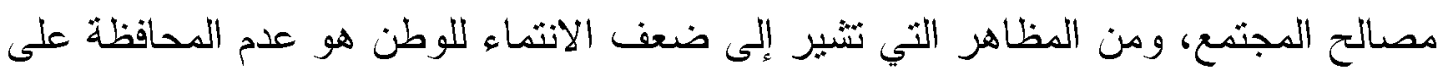

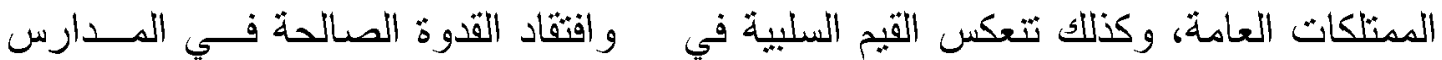
و الروتين المعوق لثشئون الحياة.

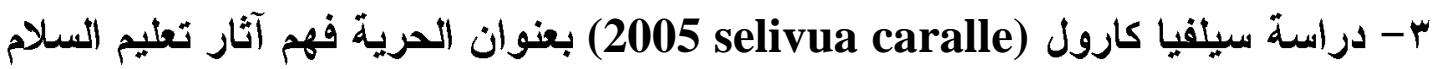

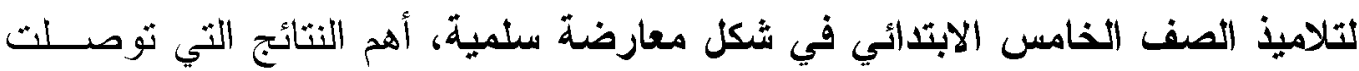
إليها الدراسة :

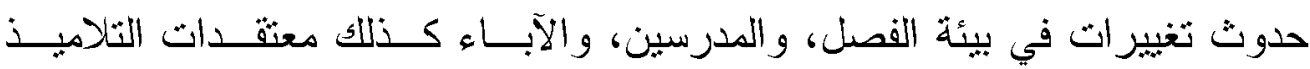
وسلوكباتهم بعد تعليم السلام في شكل مسرحيات تتاولت المعارضات بطريقة سلمية، حبـــ

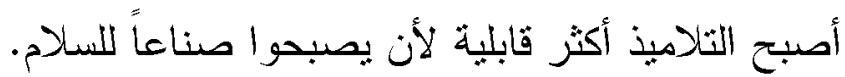

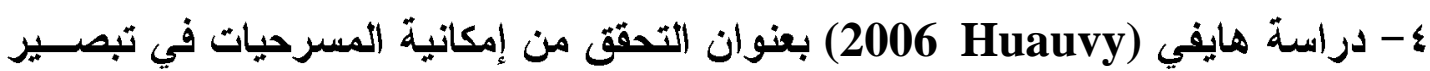

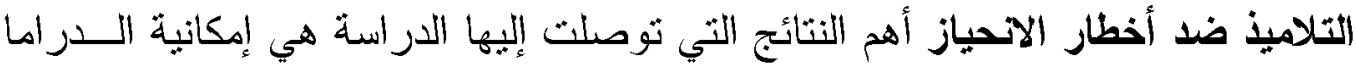

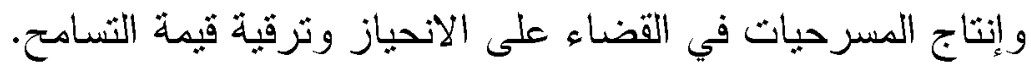
ه - دراسة 2007 Betyien Angela بعنوان إبداع المسرح السياسي للأطفال المثاهدين

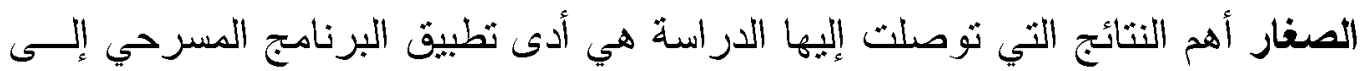

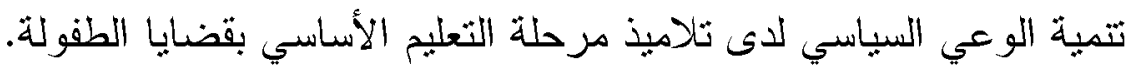

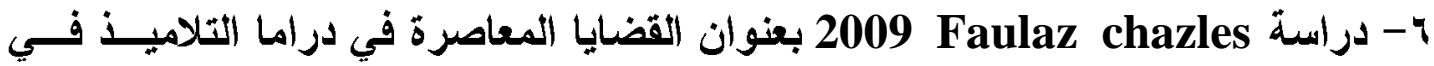

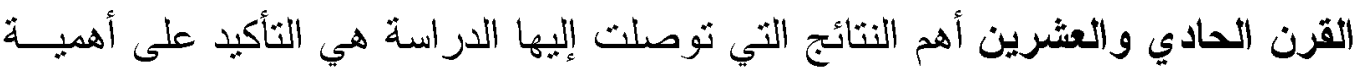

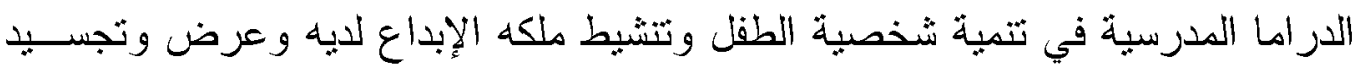

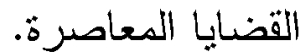


V- دراسة سوزان عبد الله 9 ، ، ب بعنوان أثر استخدام مسرح العر ائس في إكساب التلاميذ

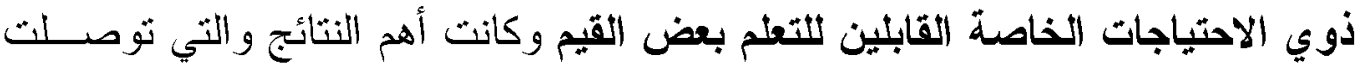

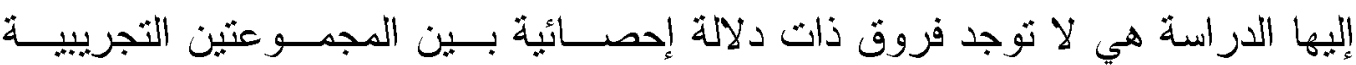

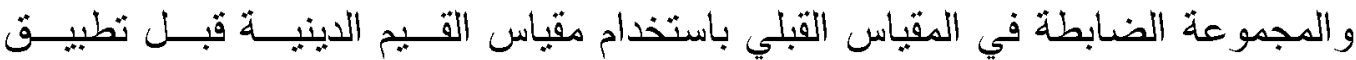

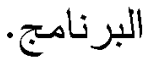

لا توجد فروف ذات دلالة إحصائية بين ذكور و إناث المجموعة التجريبية فـي المقياس البعدي باستخدام مقياس القيم الدينية لصالح الإناث.

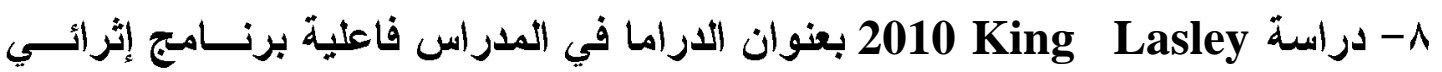

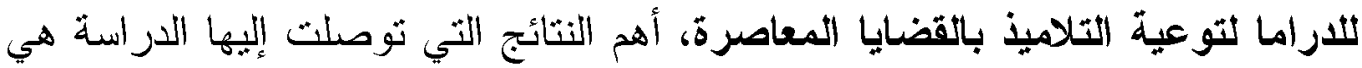

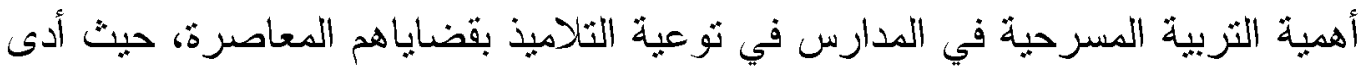

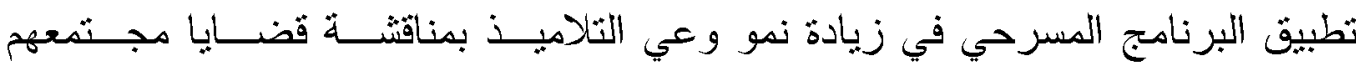

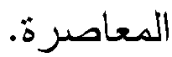
من خلال استعراض نتائج الدراسات العابق يتضح الآتي:

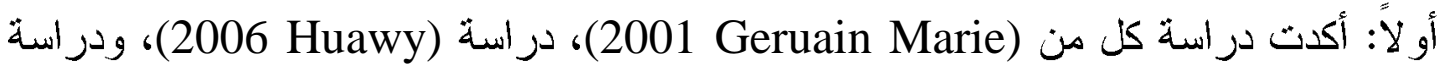
2005 Srliua Caralle)

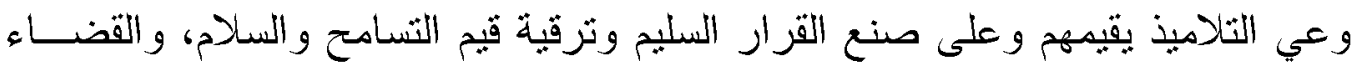
ونبذ الانحباز و التعصب.

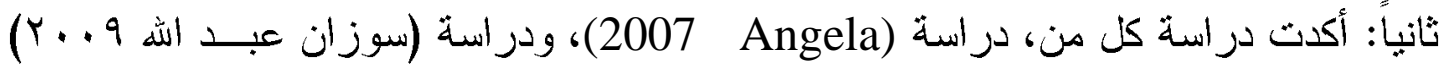
على دور القيم التزبوية والدينية في نتمية الوعي لدى التناميذ. ثالثاً: أوضحت دراسة كل من (2009 Faulez) ودراسة (2010) على دور الدراما المدرسية في توعبة التلاميذ بقضايا الطفولة المعاصرة.

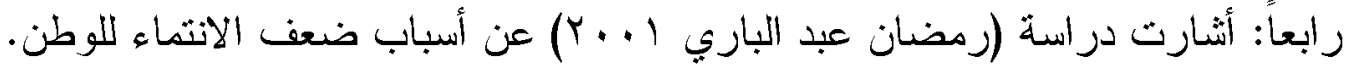

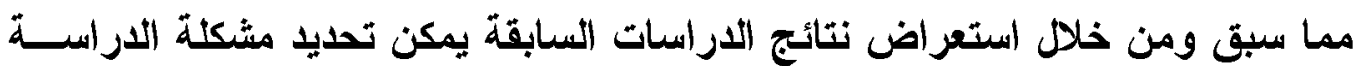
في التساؤلات الآتية: 1- ما مدى تو افر القيم السباسبة في النصوص المسرحية (عينة الدراسة)؟

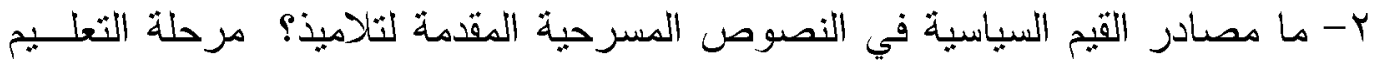
بأساسي ب- ما نوعية الثخصبات التي جسدت القيم السباسبة المقدمة للتناميذ؟ 
ع - ما نوعية اللغة المستخدمة في عرض القبم السياسية؟ 0- ما طريقة عرض القيم السياسية في النصوص المسرحية؟ ج- ما نوع الصر اع وأسلوب حله المستخدم في عرض القيم السياسية فـــي النصــوص

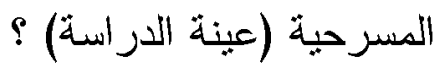

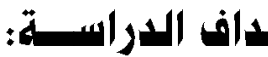

1- تحديد القيم السياسية المناسبة لتلاميذ مرحلة الطفولة المتأخرة . Y- الكثف عن القيم السياسية المتضمنة في نصوص المسرح المدرسي والمقدة لتلاميذ مرحلة الطفولة المثأخرة ومدى مناسبتها لهم. ب- التعرف على الواقع الفعلي لنشاط المسرح المدرسي داخل المؤسسات التعليمبة. ع - الوصول إلى ثوصيات ومقترحات ثوجه إلى القائمين على أمور المسرح المدرسـي داخل المؤسسات التعليمية لدفعة للاثقدم و النهوض بـه.

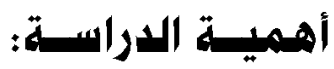

$$
\text { تتبع أهمية الدراسة من الاعتبار ات الآثية: }
$$

ا- تجمع الار اسة بين منغيرين على درجة كبيرة من الأهمية وهما القيم السياسية والمسرح

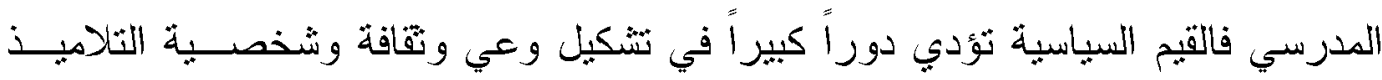

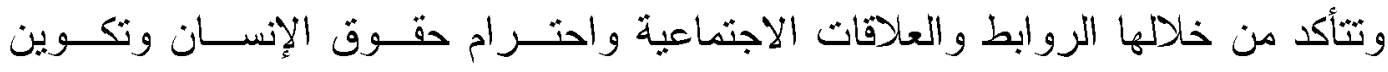
الثخصية القومبة أما المسرح المدرسي فهو يساعد التلاميذ على إيجاد حياة مستقلة لذاتهم

ويبث في نفوسهم القيم والسلوكيات الإيجابية ويخلق نقافة تثتاسب مع طبيعة المجتمع. Y- ثقديم قائمة بالقبم السياسية المثضمنة في النصوص المسرحبة و المقدمة لتلامبذ مرحلـة الطفولة المتأخرة و التي يمكن أن بسنرشد بها أخصائي المسرح المدرسي و القائمين علـى أمور تأليف الدر اما المدرسية.

س- المرحلة العمرية الموجه إليها النص المسرحي والذي تثتاوله الدراسة حيث إن التلاميـذ في هذه المرحلة العمرية يكونو أكثر استعداداً لتعلم القبم والمعايير السباسية. ع- قد بستفبد منها الباحثون والقائمون على الاتصال والمهتمون بمجال الإعلام والمسرح عن

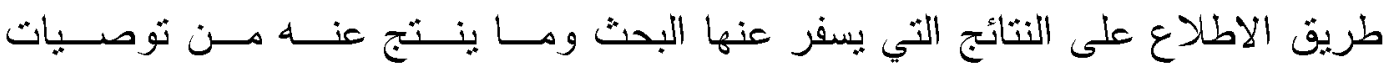
ومفترحات. 


\section{الإجراءات المنهجية للدراسة:}

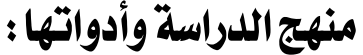

اعتمدت الدراسة على المنهج الوصفي النحليلي وتحليل المحتوى لمجموعة عمدية من النصوص المسرحية التي تتوافر فيها القيم السياسية المناسبة لتلاميذ مرحلة الطفولة المتأخرة

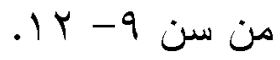

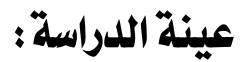

وتتشمل مجموعة النصوص المسرحبة التي قدمت على خشبة المسرح المدرسي فـي

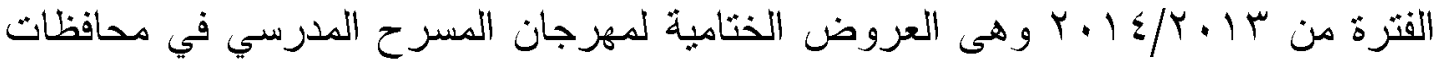
القليوبية، والجيزة والقاهرة، إقليم القاهرة الكبرى وقد ثم اختيار عينة عمدية من النصــوص

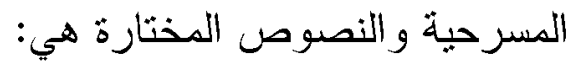
1- دسرحبة العصافير تأليف إيمان فاروق ددرسة على الدبيس، إدارة شــيين القنـاطر محافظة القليو بية. Y- مسرحية حكاية لم تتنهي بعد تأليف شريف شمس الدين إدارة مصر الجديدة محافظة

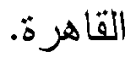

r- مسرحية سلطان آخر الزمان ثأليف محمد عايش إدارة العمرانبة محافظة الجيزة. ؟- مسرحية السيف الذهبي إعداد علي عرفة إدارة الهرم محافظة الجيزة. 0- مسرحية كلنا عايزين صورة إعداد محمد سلطان إدارة السيدة زينب محافظة القاهرة. 7- مسرحبة أبو خريبة على التل ثأليف محمد حسن سليمان مدرسة رياضية الصالحين إدارة شبرا الخيمة محافظة القليو بية.

$$
\text { جـدود الدراســلة: }
$$

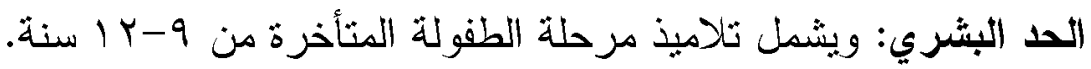

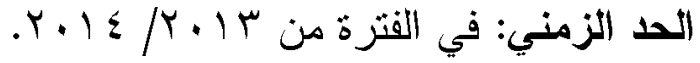

الحد المكاني: إقليم القاهرة الكبرى و الذي يشمل دحافظات القاهرة و الجيزة القليوبية.

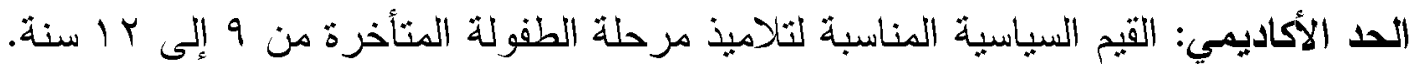


ونقصد بها معيار الحكم على كل ما يؤمن به مجتمع ما مــن المجتمعـات البشــــية

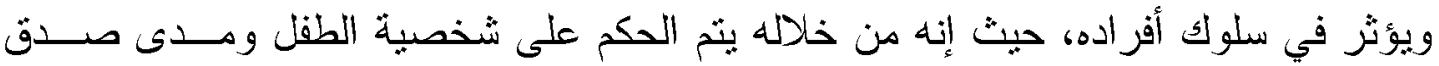

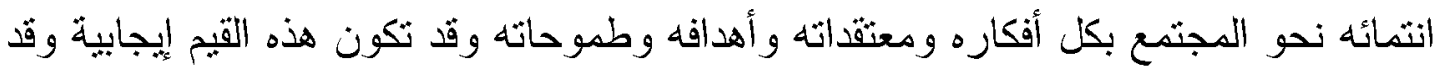

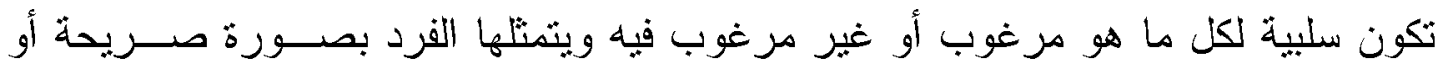

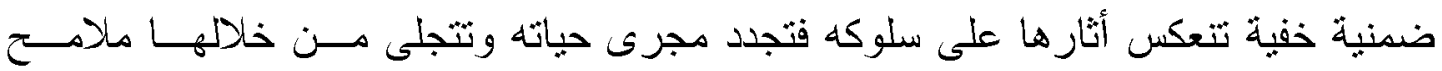

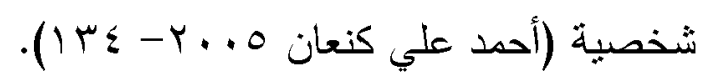

المسرح الملدرسي:

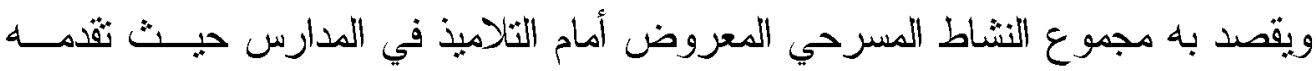
فرقة المدرسة إعمالاً مسرحية بين جدران المؤسسة النعليمية لجمهور ينكون من زملائهم وأستاتنته

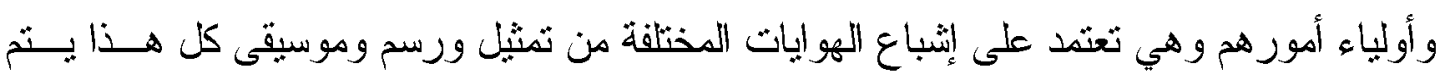

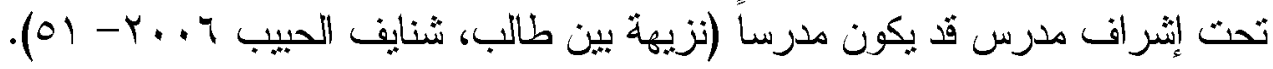

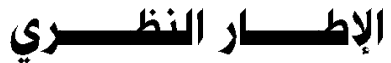 المسرح المدربي والقيم السياسية النية}

القيمة هي كل صفة ذات أهبية لاعنبارات نفسبة، أو اجنماعية، أو أخلافية، أو جماليـة،

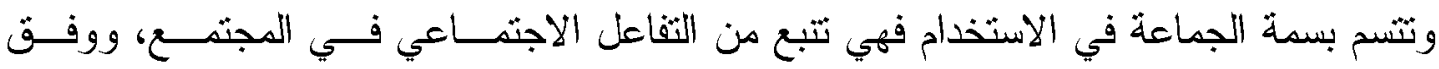

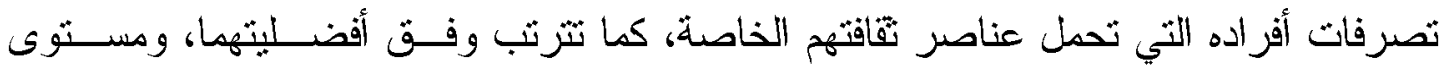

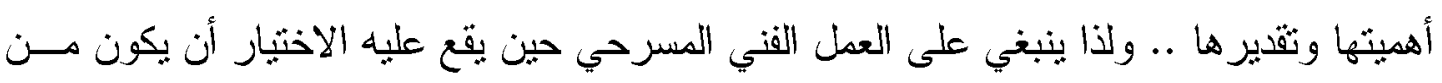

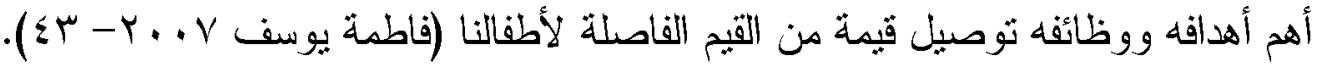

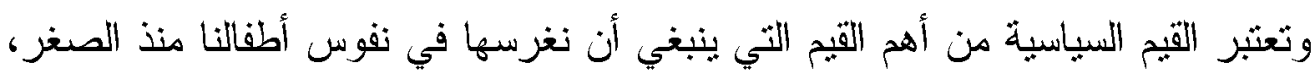

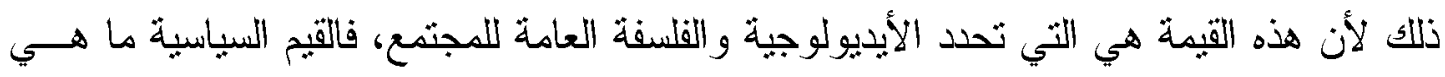

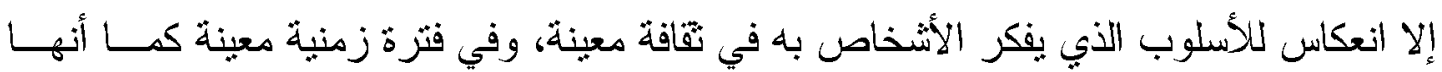

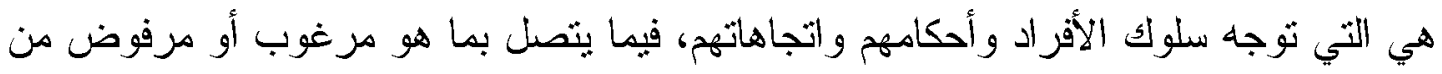

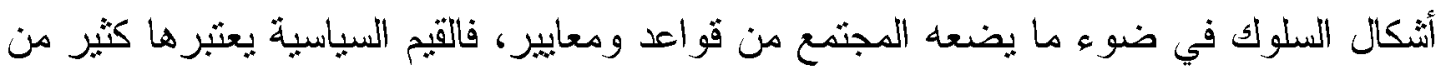

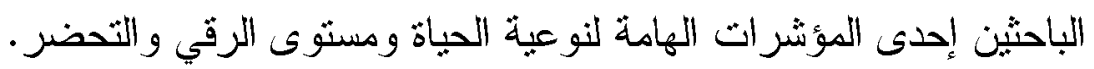




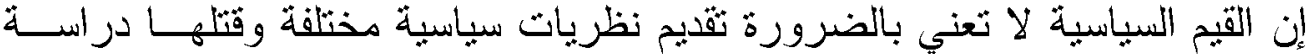

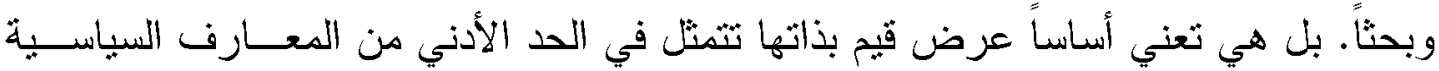

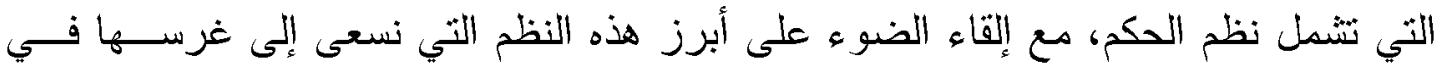

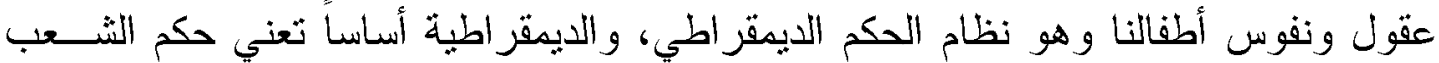
عن طريق الشعب ومصطلح الديمقراطية Demacrathy مثتق من الكلمة اليونانية Demas مئية وتعني الثتب Kmatia ومعناها السلطة على عكس ما يطلق عليه حكم الأقلية Atigarchy

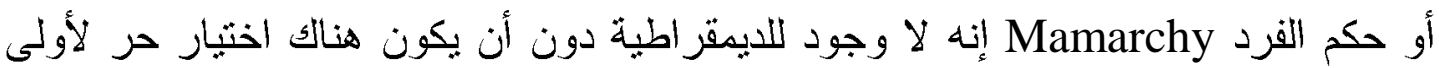

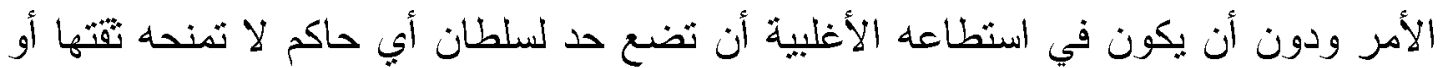

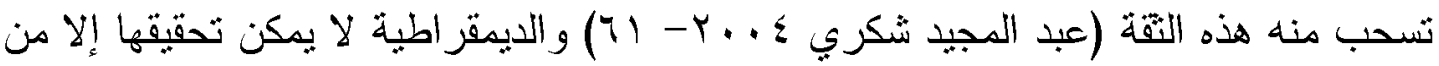

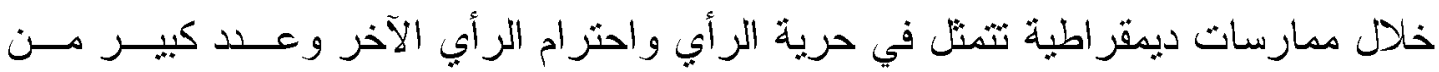

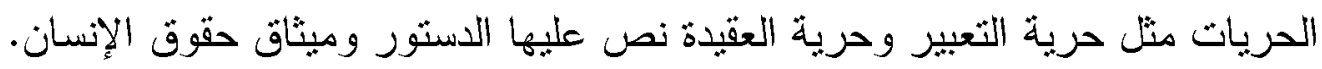
كما جاء السلام بالعديد من القبم السياسية الرئيسية التي لها شأن كبير في حياة الإنسان

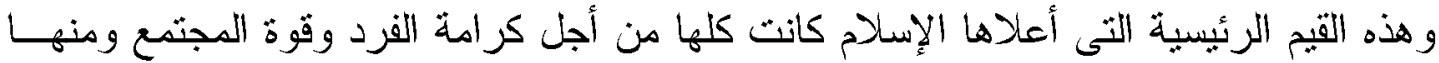

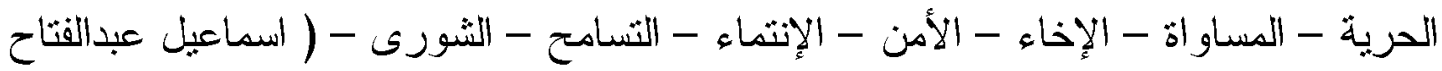

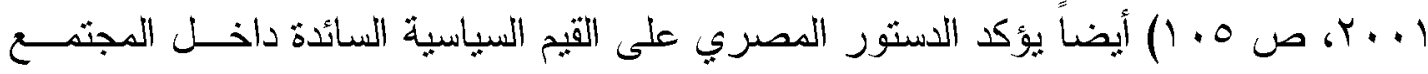

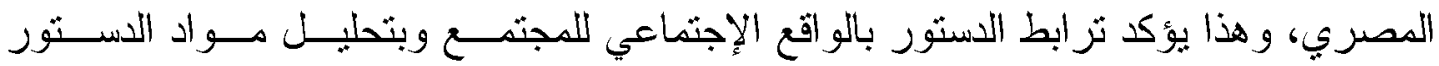

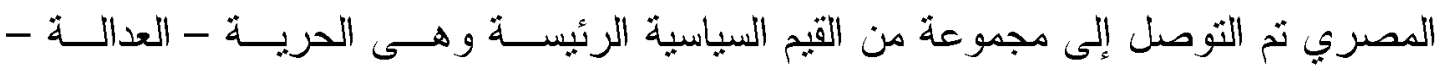

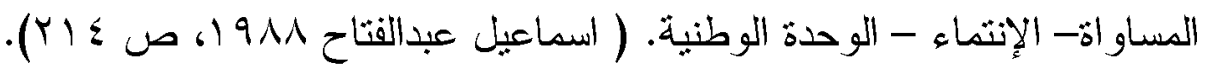
وقد قامت الدراسة الحالية بإنشتقاق القيم السياسية من هذه المصادر .

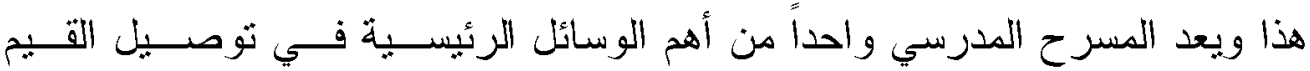

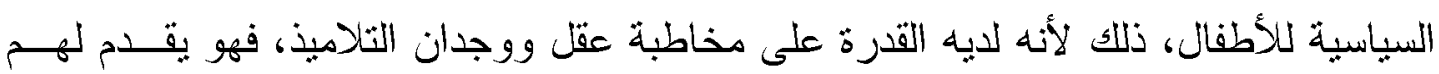

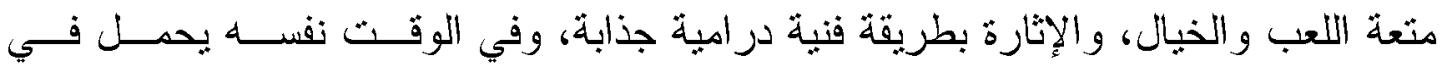

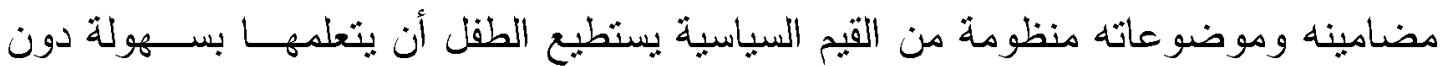

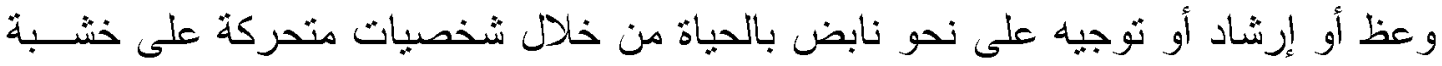
المسرح الأمر الذي يجعله وسيلة هامة من وسائل ثربية الطفل وتنمية شخصيثة.

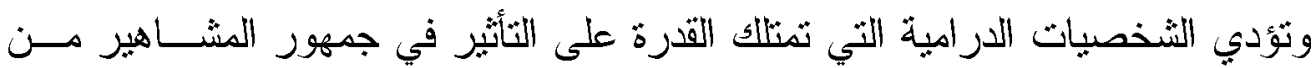

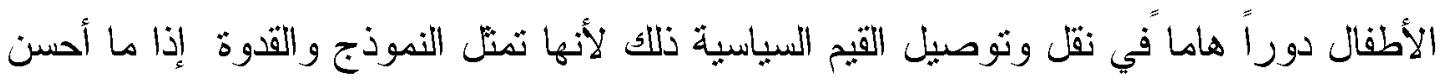
اختيار ها وتوظيفها في الدراما بما يحقق الثتأثير الفعال على شخصية الطقل وذلك من خلاله الحالة 


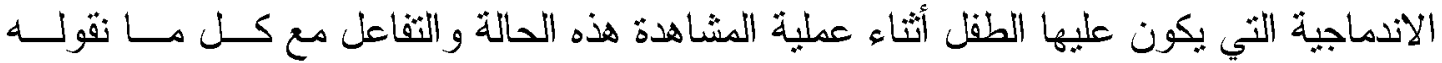
وتصدر عن الثخصبة لها تأثير ها على الطفل المتلقى ولذلك لابد أن نكون هذه الثخصبات سوية

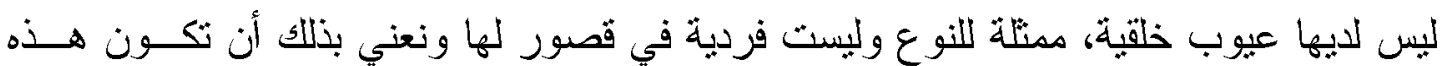

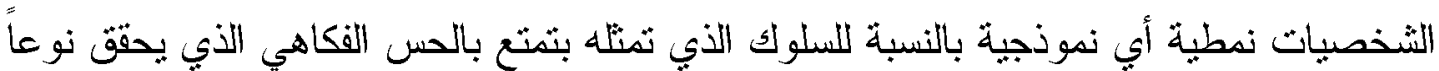

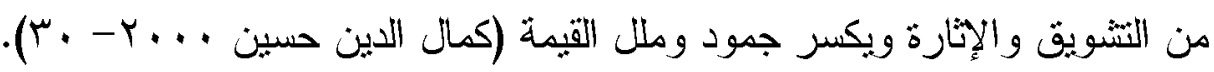

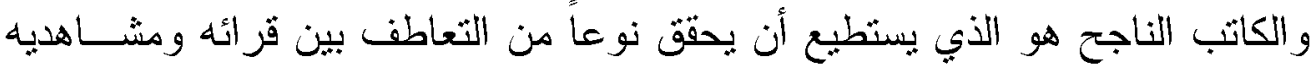

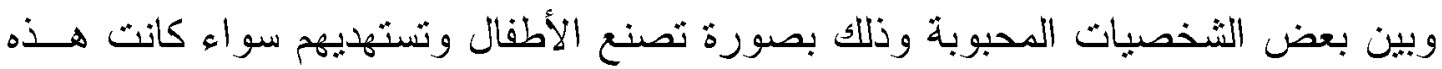

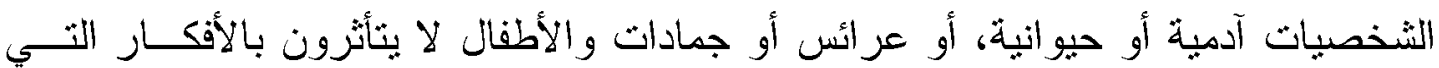

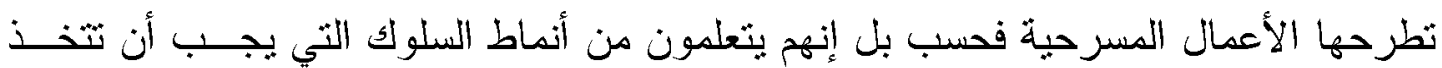
وقو اعد الأخلاق التي يؤمنون بها في كل موقف جديد.

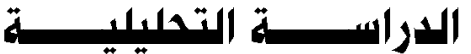

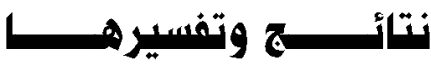

\section{مقدمهـــة:}

تهذف هذة الدراسة إلى عرض نتائج نحليل مضمون النصوص المسرحية - عبنــة الدراسة - و المقدمة لتلاميذ مرحلة التعليم الأساسي.

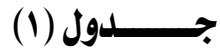

نسب تكرار ظهور القيه السياسية في النصوص المسرحية عينة الدراسة

\begin{tabular}{|c|c|c|c|c|c|c|}
\hline \multicolumn{2}{|c|}{ الإجمالي } & \multicolumn{2}{|c|}{ تكرارضمني } & \multicolumn{2}{|c|}{ تكرارصريح } & \multirow{2}{*}{ قيم السياسية التكرار } \\
\hline$\%$ & s & $\%$ & 5 & $\%$ & st & \\
\hline$\% r \xi, \& \Lambda$ & $\Lambda \cdot$ & $\% / r, 9 r$ & r. & $\%, r I, 0$ & 0. & العدل \\
\hline$\% \mid \Lambda, 1$ & sr & $\%$ \%,rr & iv & $\% 1 \cdot, Y V$ & ro & الانتماء \\
\hline$\% r \varepsilon, 1 r$ & 07 & $\% 9, \cdot 0$ & MI & $\% 10, \bullet 1$ & ro & الحرية \\
\hline$\% 1 \cdot, v V$ & ro & $\% r, \mathfrak{\xi}$ & $\wedge$ & $\%$ \% rr & iv & السلاه \\
\hline$\% \wedge, 7 r$ & r. & $\% r, 01$ & 7 & $\%\urcorner, \bullet r$ & 18 & المشاركة \\
\hline$\% r, \llbracket 飞$ & $\wedge$ & $\% 1, \wedge 71$ & $r$ & $\%, r, 0 \Lambda$ & 7 & المساواة \\
\hline- & - & - & - & - & - & المبادرة \\
\hline$\% \cdot, \xi r$ & 1 & $\%,\{r$ & 1 & - & - & الديمقراطية \\
\hline$\% 1$. & rrT & $\%$ \% & 10 & $\%$ \%r, rq & I\&V & الإجمالي \\
\hline
\end{tabular}




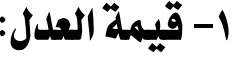

ظهرت قيمة العدل لتحتل الترتبب الأول بين القيم السباسية الأخرى بإجمالي نكــرار

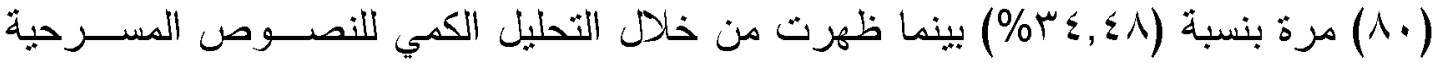

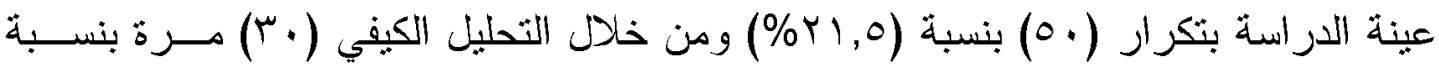
.$(\% \backslash r, 9 r)$

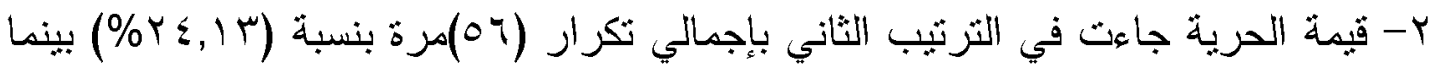

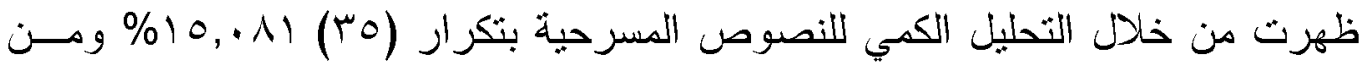

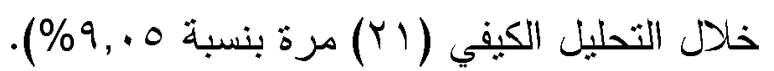

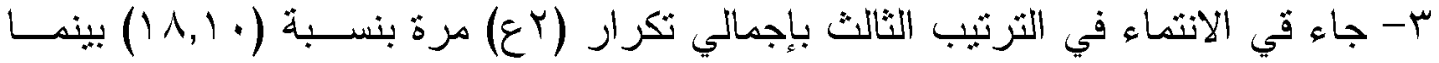

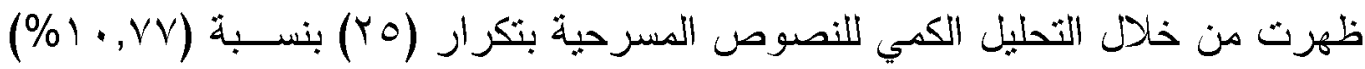

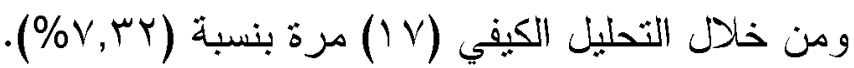

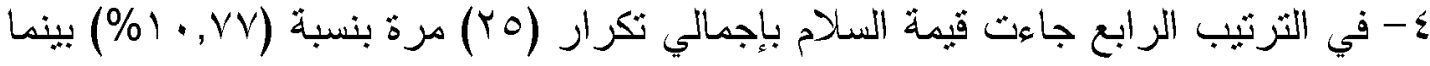

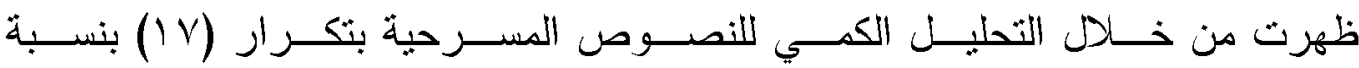

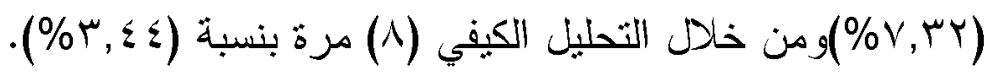

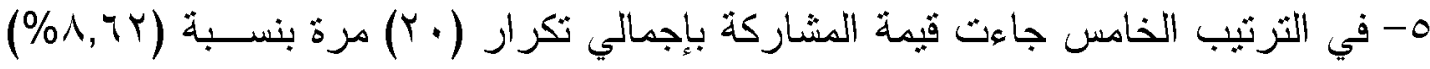

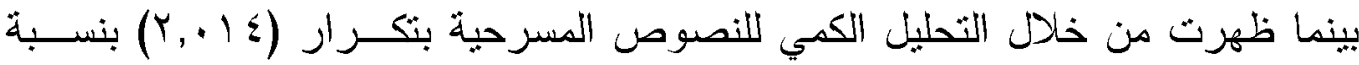

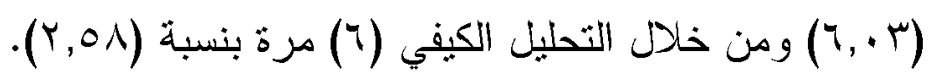

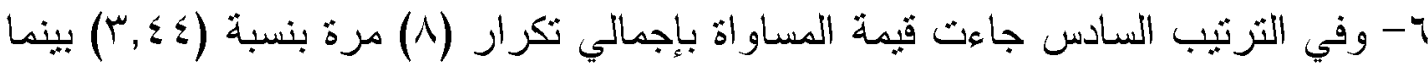

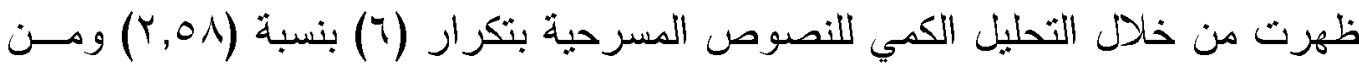

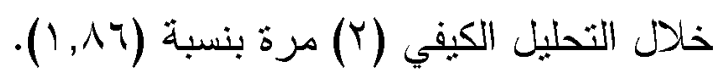

V- وفي الترتيب السابع جاءت قيمة الايمقراطية بإجمالي نكرار (1) مرة بنسـبة (استح , ) بينما من خلال التحليل الكمي بينما ظهرت خلال التحليل الكيفي (1) مرة بنسبة (باع , · )

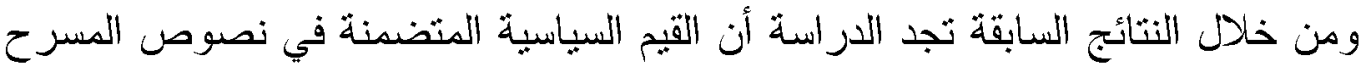

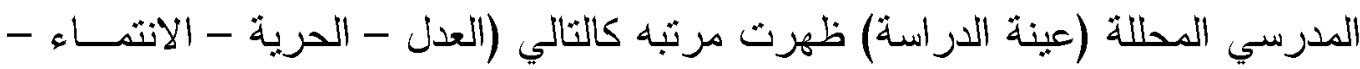

$$
\text { السلام - المشاركة - المساو اة - الايمقر اطية). }
$$

ونزى الدراسة أن ظهور هذه القيم بنسبة عالبة يؤكد على اهتمام الكاتب بضــرورة

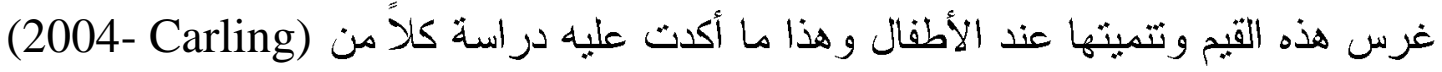
ودراسة (2006) - Havy). 


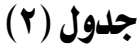

يوضح طريقة عرض القيه السياسية في النصوص المسرحية

\begin{tabular}{|c|c|c|c|c|c|c|c|c|}
\hline \multicolumn{2}{|c|}{ الإجمالي } & \multicolumn{2}{|c|}{ من خلال التعبير } & \multicolumn{2}{|c|}{ من خين الشخصل الحوار } & \multicolumn{2}{|c|}{ من خلال سرد } & \multirow{2}{*}{ القيه السياسية طريقة عرض القيه } \\
\hline$\%$ & st & $\%$ & st & $\%$ & st & $\%$ & st & \\
\hline$\% 1 \wedge, \vee 0$ & $\Delta \xi$ & $\% \Delta, r$ & 10 & $\% \wedge\rceil$, & ro & $\% \varepsilon, \Lambda$ & $1 \varepsilon$ & العلل \\
\hline$\%$ Yr, OY & 70 & $\% \eta, r$ & $M$ & $\% q, r$ & $r V$ & $\% 1 \cdot, \xi$ & r. & الانتماء \\
\hline$\%$ IV, rq & 0. & $\% r, r$ & MI & $\% \varepsilon, \wedge$ & 18 & $\% \Delta, r$ & 10 & الحرية \\
\hline$\% \wedge, 7 \wedge$ & ro & $\% 1, \vee$ & 0 & $\% 0,0$ & 17 & $\% 1, r$ & $\xi$ & السلاه \\
\hline$\% q, \cdot r$ & M & $\% 1, r$ & $\varepsilon$ & $\% r, 1 \xi$ & 1. & $\% \varepsilon, 1$ & ir & المشاركة \\
\hline$\% 1 r, 10$ & ro & $\% 1$ & $r$ & $\% \wedge\rceil$, & ro & $\%, r, \xi$ & $r$ & المساواة \\
\hline$\% r, \leqslant r$ & 1. & $\% \cdot, 7$ & $r$ & $\% 1$, & $r$ & $\% 1, \vee$ & 0 & المبادرة \\
\hline$\%\{, 01$ & ir & $\% r$ & 7 & $\% 1, \vee$ & 0 & $\%, 7$ & $r$ & الديمقراطية \\
\hline$\% 1$. & YAA & $\%$ Y,$Y$ & v\& & $\%$ \% & iro & $\% r, \cdot q$ & 19 & الإجمالي \\
\hline
\end{tabular}

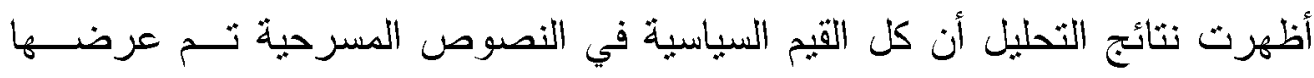

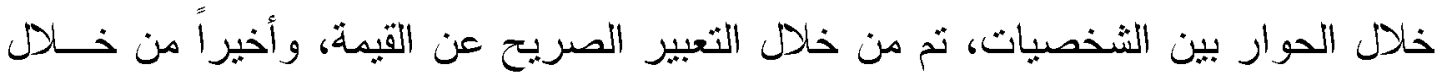

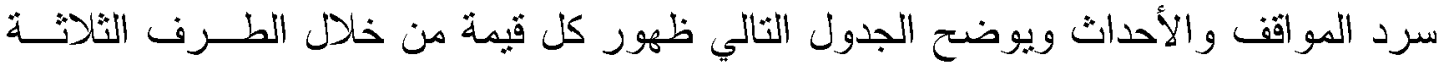
السابقة بنسب متفاوتة.

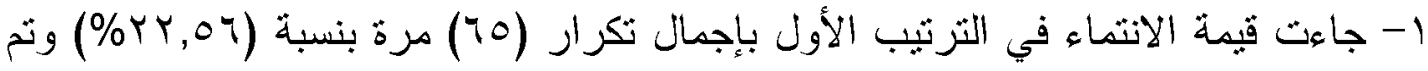

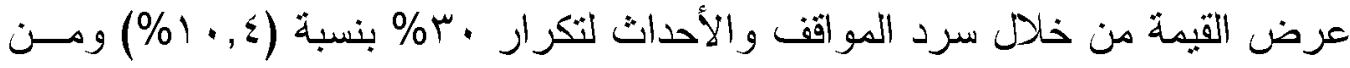

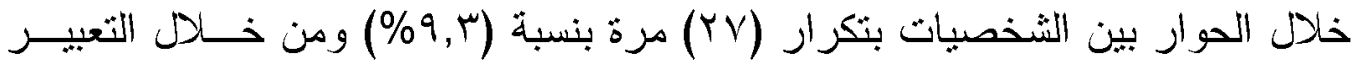

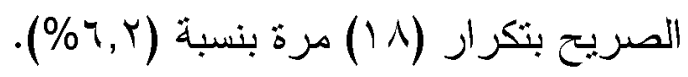

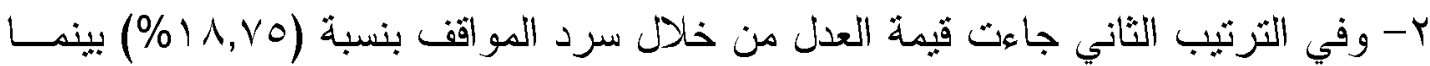

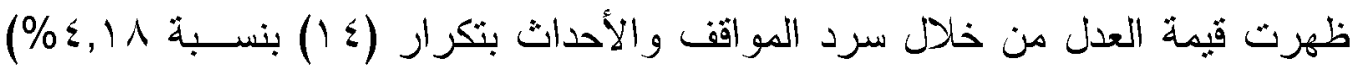

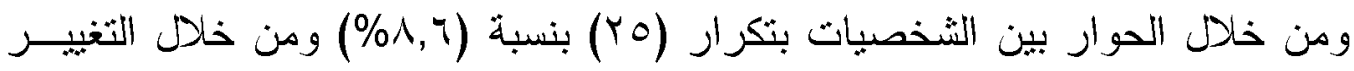

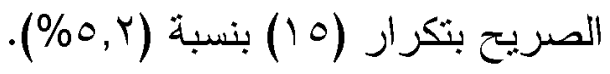

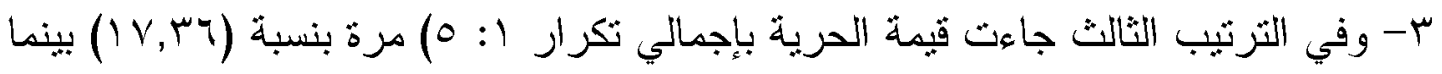

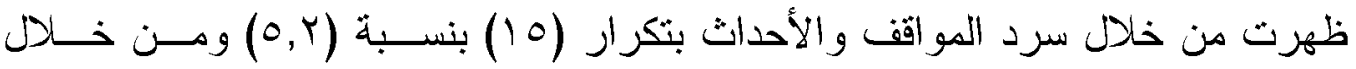

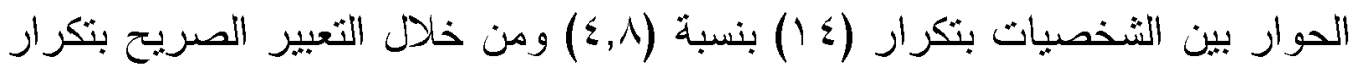

$$
\text { . }(Y, Y)(Y)
$$




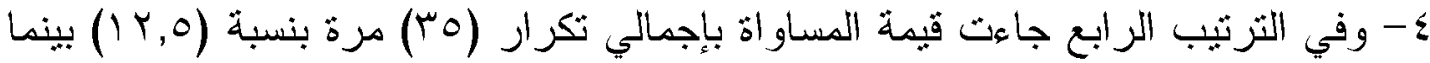

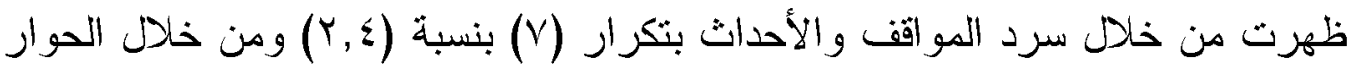

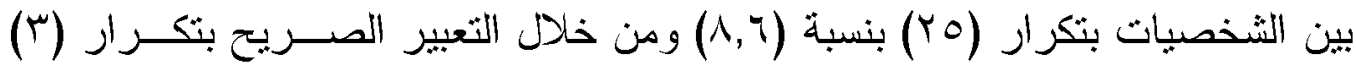

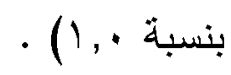

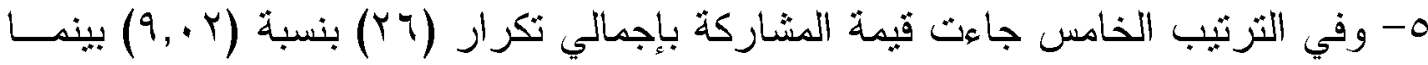

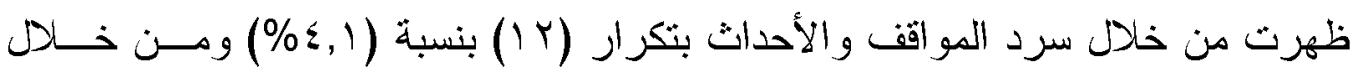

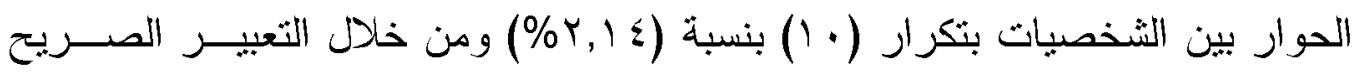

$$
\text { بتكر ار (ع) بنسبة (ب, (\%). }
$$

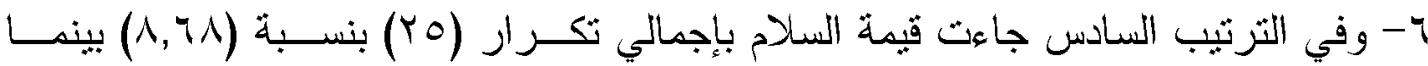

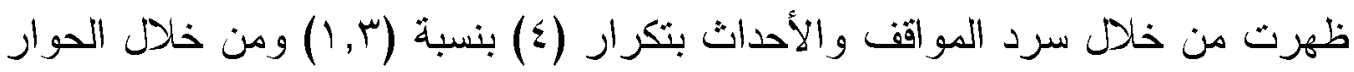

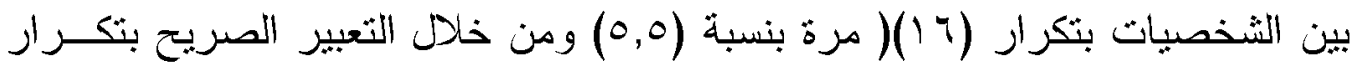

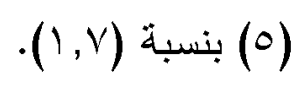

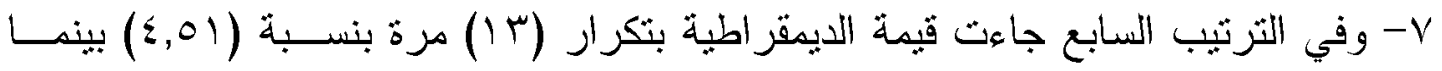

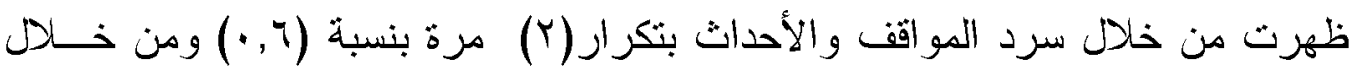

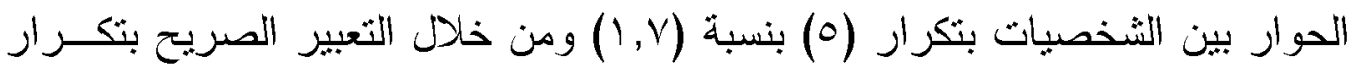

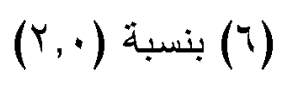

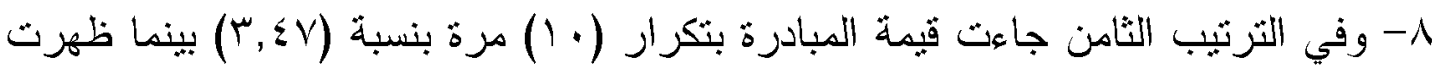

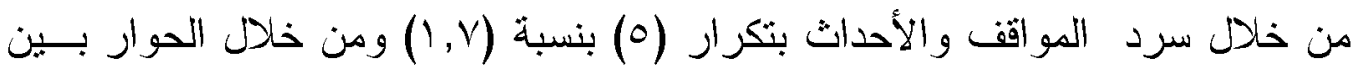

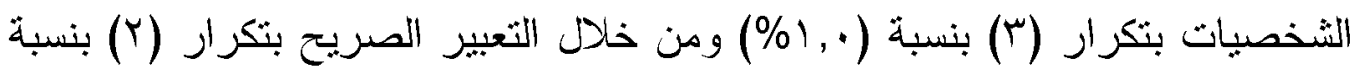

$$
\text { . }(\% \cdot 7)
$$

تجد الدراسة أن طريقة عرض القيمة تؤثر في معرفة وتقبل الأطفال لهذه القيمة فمثلًا

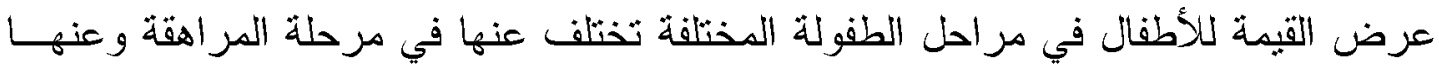

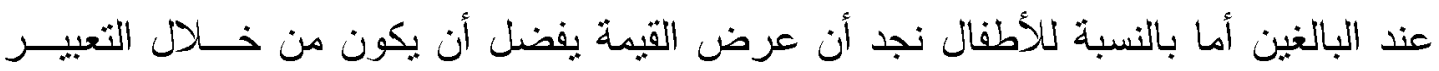

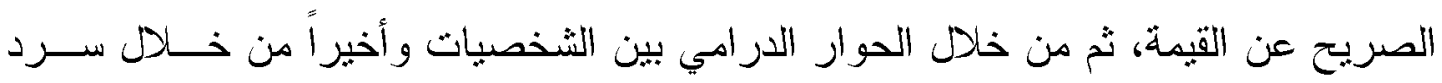

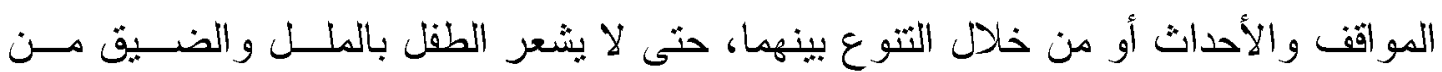

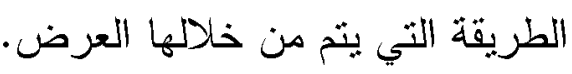




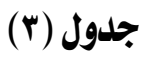

يبين ملى وضوح موقف المؤلف من القيمة السياسية

\begin{tabular}{|c|c|c|c|c|c|c|c|c|}
\hline \multicolumn{2}{|c|}{ الإجمالي } & \multicolumn{2}{|c|}{ الإشارة إلى موقفة من } & \multicolumn{2}{|c|}{ تلمبلدو في المسرحية روح لهذه القيمة } & \multicolumn{2}{|c|}{ تبلدو في المسرحية } & \multirow[t]{2}{*}{ موقف المؤلف } \\
\hline$\%$ & st & $\%$ & st & $\%$ & $s$ & $\%$ & st & \\
\hline - & ir. & $r q, O$ & $1 .$. & - & - & $0, r$ & r. & العدل \\
\hline - & 7. & $0, r$ & r. & - & - & $1 \cdot, 7$ & $\xi$ & الانتماء \\
\hline- & 09 & 7,7 & ro & - & - & $\Lambda, r$ & $r$ & الحرية \\
\hline- & rA & $\xi, \curlyvee$ & $1 \cdot 1$ & - & - & $0, r$ & r. & السلاه \\
\hline- & $7 r$ & $r, 1$ & ir & - & - & Ir,Ir & 0. & المشاركة \\
\hline- & 17 & $\xi, r$ & 17 & - & - & - & - & المساواة \\
\hline- & 19 & $0, \bullet$ & 19 & - & - & - & - & المبادرة \\
\hline- & 7 & 1,0 & 7 & - & - & - & - & الديمقراطية \\
\hline$\% 1 \ldots$ & rrV & $\% \Delta v, r$ & r19 & - & - & \&r,Y & 171 & الإجمالي \\
\hline
\end{tabular}

بتضح دن الجدول السابق وجود تتوع لموقف المؤلف بين روح الثأييد للقيم والمحايدة التامة، ولم نظهر للمؤلف روح المعارضة لهذه القيم. لمان.

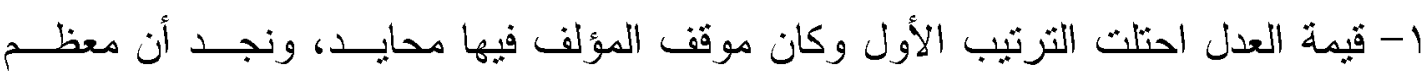

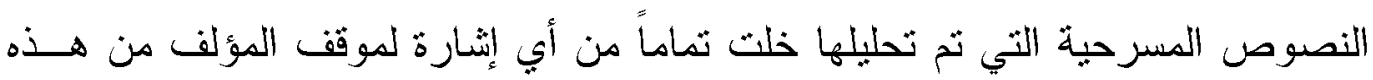
القيمة بنسبة تكر ار (.r\%) ولم تظهر روح المعارضة لها، ولكن ظهر روح التأيبد لها

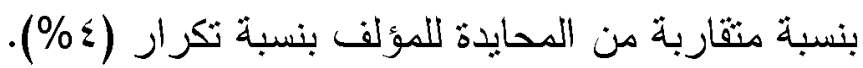

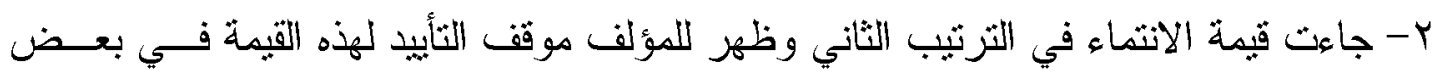
النصوص بنسبة نكرار (7 (1\%) ولم تبد روح المعارضة لها في أي من النصوص المسرحية المحلاة ولكن في البعض الآخر لم تظهر للمؤلف أبي موقف من القيمة بنسبة نكرار (ع\%). س- وفي الترتيب الثالث جاءت فيه الحرية فقد ظهرت للمؤلف روح التأيبد لها بنسبة نـــرار ولم نظ, (\%)

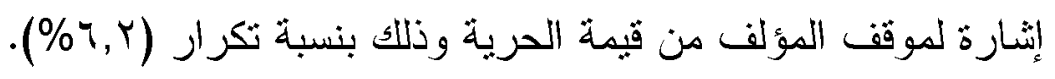

ع- وفي الترتيب الرابع نجد قيمة السلام حيث ظهر للمؤلف وموقف التأيبد لها بنسبة تكرار (؟) ولكن أحياناً نجد خلو النصوص من أي إثـارة لموقف المؤلف تجاه السلام بنسبة

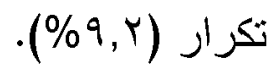


0- وفي الترتيب الخامس نجد قيمة المشاركة حيث نجد موقف التأييد منها من قبل المؤلــــ

$$
\text { بتكرار (1\%) ومحايد بنسبة نكرار (2,11\%). }
$$

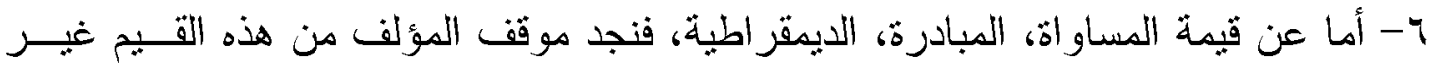
مؤيد لها وكذلك غير معارض ولكن نخلو المسرحبات التي تم تحليلها مسن أي إثنــارة لموقف المؤلف تجاه هذه القيمة وذلك بنسبة نكرار (•, (1\%) لقيمة المساواة، (Y,0\%) لقيمة المبادرة (Y, (1) لقيمة الديمقر اطية. يظهر موقف المؤلف من القيمة أساساً جوهرياً من ثقبل الطفل لهذه القيمة أو رفضها

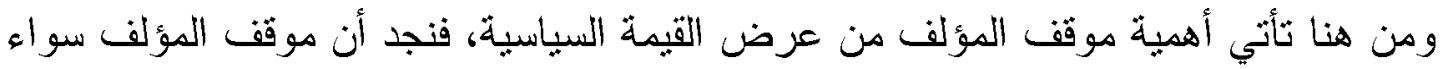

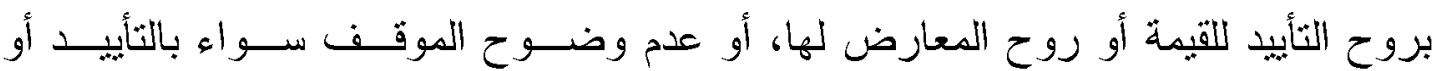

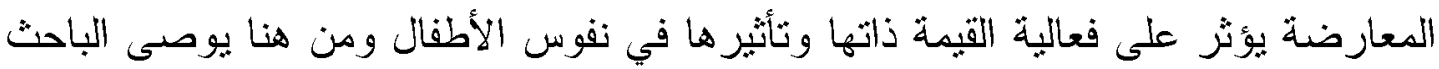
بضرورة وضوح موقف المؤلف الدرامي من القيم السياسية.

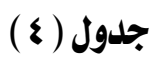

يبين نوع الشخصية التي صدرت عنها القيم السياسية

\begin{tabular}{|c|c|c|c|c|c|c|c|c|}
\hline \multicolumn{8}{|c|}{ بشرية } & \multirow{3}{*}{ القيه السياسية } \\
\hline \multicolumn{2}{|c|}{ شيوخ } & \multicolumn{2}{|c|}{ رجال } & \multicolumn{2}{|c|}{ شباب } & \multicolumn{2}{|c|}{ أطفال } & \\
\hline$\%$ & st & $\%$ & St & $\%$ & st & $\%$ & s & \\
\hline & & $\% 1$ & 0. & $\% 1$ & r. & $\% \curlyvee, \boldsymbol{\xi}$ & ir & العدل \\
\hline & & $\%$ & ro & $\% 9,7$ & rr & $\% 1,7$ & $\wedge$ & الانتماء \\
\hline & & $\% 1,7$ & $\wedge$ & $\% \&, 7$ & rr & $\% r$ & 10 & الحرية \\
\hline & & $\% 0,7$ & $r \wedge$ & $\% 1$ & $r$. & $\% \cdot$, ₹ & $r$ & السلاه \\
\hline & & $\% 1, r$ & 7 & $\% \varepsilon, r$ & rI & $\% \varepsilon, \xi$ & rr & الشاركة \\
\hline & & $\% \varepsilon$ & $r$. & $\% 1,1$ & 9 & & $r \cdot$ & المساواة \\
\hline & & $\% \varepsilon$ & $r$. & $\% \bullet, \wedge$ & $\varepsilon$ & - & - & المبادرة \\
\hline & & $\%, 7$ & $r$ & $\% \cdot, 7$ & $r$ & - & - & الديمقراطية \\
\hline & & & & & & & & الإجمالي \\
\hline
\end{tabular}

1- ظهرت قيمة العدل على لسان مجموعة من الكبار بنسبة تكرار (· (\%) ثم على لســان

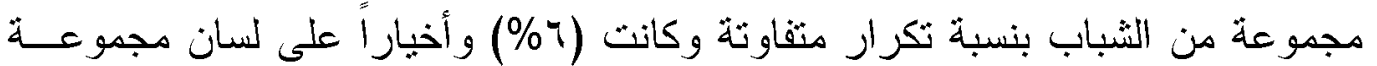

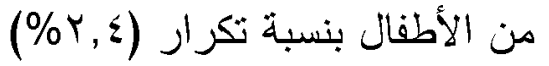


Y-قيمة الإنتماء في النصوص المسرحبة على لسان مجموعة من الثـــباب بنســبة نكــــار

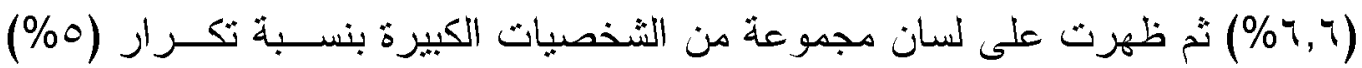

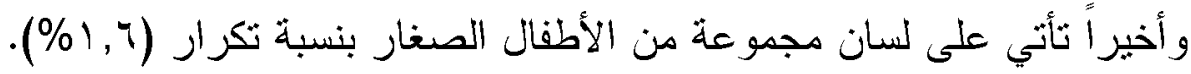

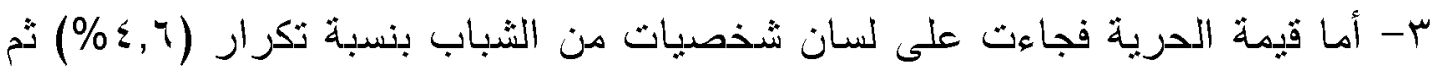

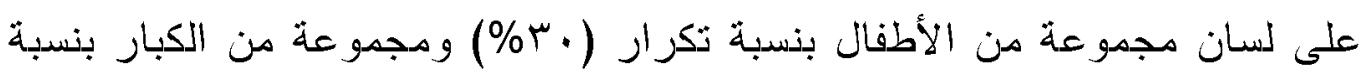

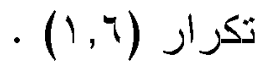

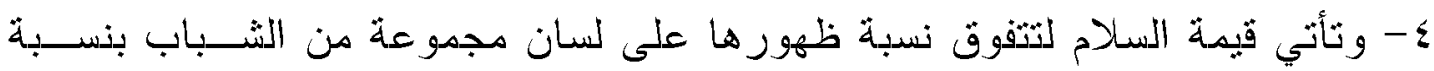

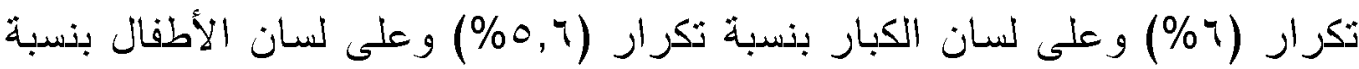

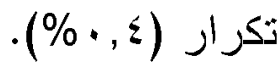

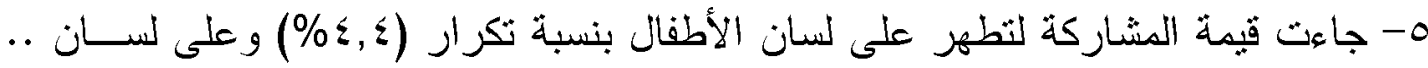

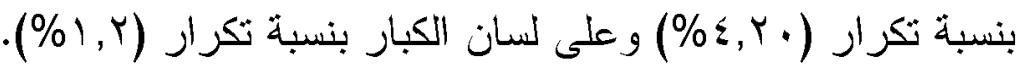
צ- تظهر قيمة المساو اة لتتساوى نسب ظهور رها على لسان مجمو عة من الأطفــال و الكبــار

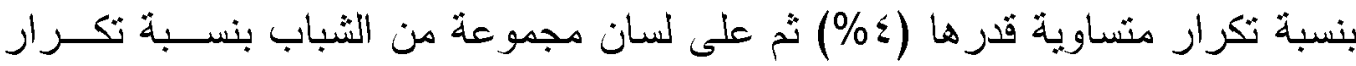
$.(\%), \lambda)$

V- تأتي قيمة المبادرة لنظهر في النصوص المسرحية على لسان مجموعة الكبــار بنســة

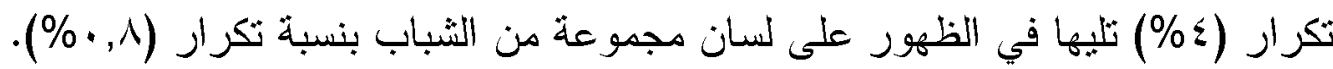

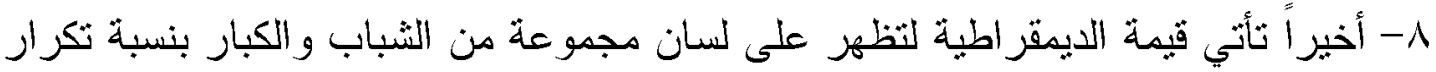
متساوية (T, •\%) ولم تظهر على لسان أب مجموعة من الأطفال.

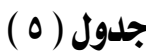

نسبة ظهور كل قيمة من خلال اللفة (فصحى - فصحى بسيطة - لهجة عامية)

\begin{tabular}{|c|c|c|c|c|c|c|c|c|}
\hline \multicolumn{2}{|c|}{ الإجمالي } & \multicolumn{2}{|c|}{ لهجة عامية } & \multicolumn{2}{|c|}{ فصحى بسيطة } & \multicolumn{2}{|c|}{ فصحى } & \multirow[t]{2}{*}{ اللفة } \\
\hline$\%$ & St & $\%$ & S & $\%$ & st & $\%$ & S & \\
\hline & & $\%, r, q$ & 10 & $\% 9, r$ & or & $\% 9$ & or & العدل \\
\hline & & $\% r, r$ & 19 & $\% \wedge, r$ & $\{V$ & $\% 0,9$ & $r \varepsilon$ & الانتماء \\
\hline & & $\% 1, Y$ & 1. & $\% \vee, r$ & $\{r$ & $\% r, 1$ & IN & الحرية \\
\hline & & $\%, r, \xi$ & 18 & $\% 7,1$ & ro & $\% \varepsilon$, & rr & السلاه \\
\hline & & $\% 1, r$ & $\Lambda$ & $\% 1,7$ & rA & $\% r, \xi$ & $r$. & الشاركة \\
\hline & & - & - & $\% 1,1$ & $\xi$ & $\% 1, r$ & $\Lambda$ & المساواة \\
\hline & & $\% 1$, & 9 & $\% \%, \xi$ & r. & $\% \cdot, \cdot 0$ & $r$ & المبادرة \\
\hline & & - & - & $\%, \wedge$ & 0 & $\% \cdot, r$ & $r$ & الديمقراطية \\
\hline & orr & $\% 1 r, v$ & vr & $\% .09, \&$ & $r \varepsilon$ & $\% r r, q$ & 17. & الإجمالي \\
\hline
\end{tabular}


يتضح من خلال الجدول السابق أن النسب الأعلى لظهور القيم السباسبة تأتي مـن

خلال اللغة الفصحى المبسطة تليها اللغة الفصحى وفي النهاية اللهجة العامية.

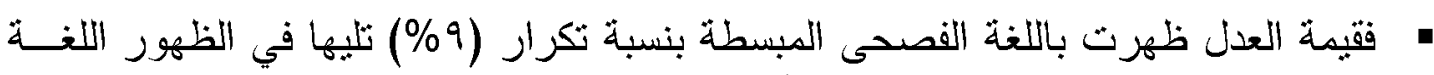

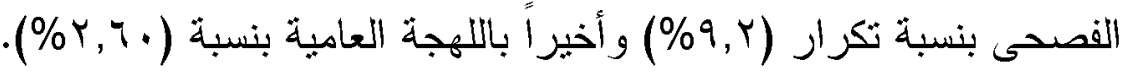

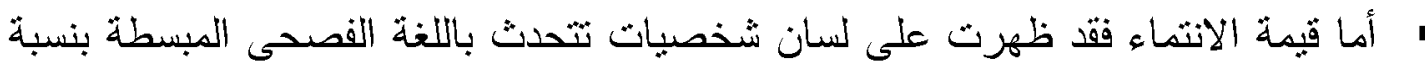

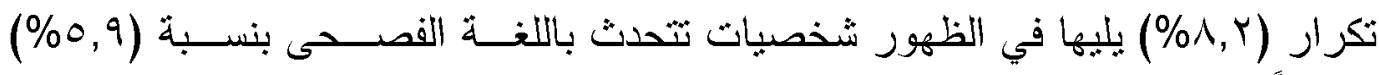

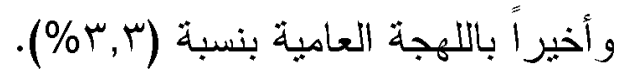

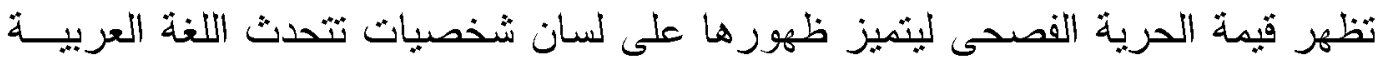

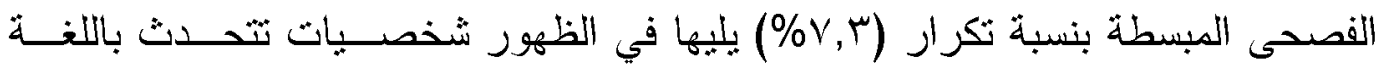

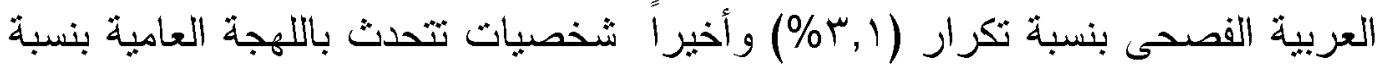
تكرار (1, (\%).

وتأثي قيمة السلام على لسان شخصبات تثحدث بالفصحى المبسطة بنسبة نكرار (1, ؟4\%)

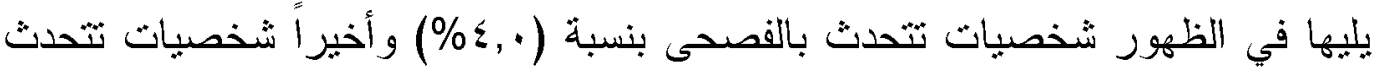

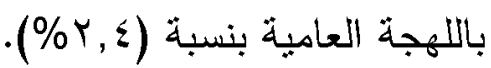
• أما قيمة المشاركة فظهرت على لسان شخصبات تتحدث باللغة العربية الفصحى المبسطة

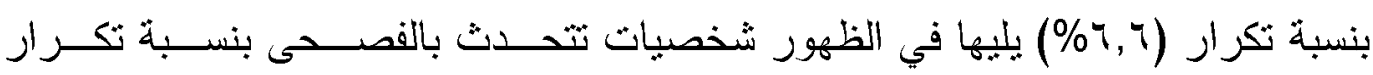

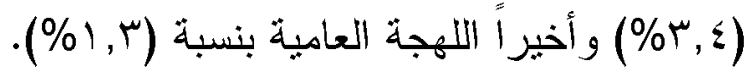

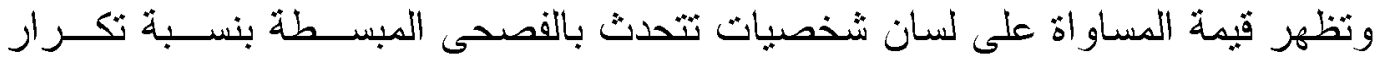

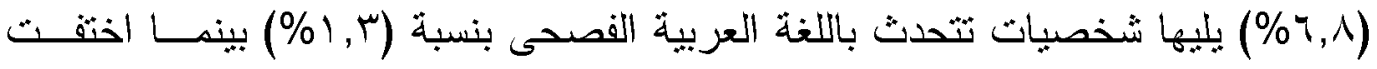
نسبة الثخصبات الني تثحدث باللهجة العامية.

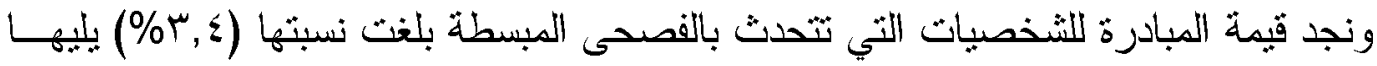

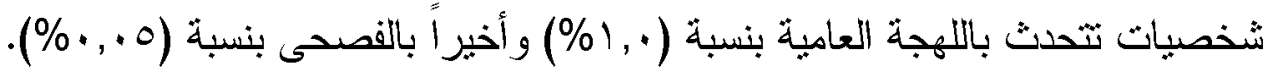

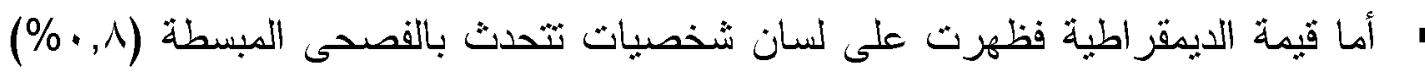

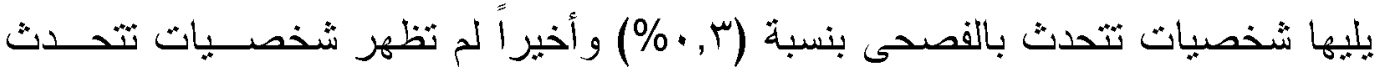
باللهجة العامية.

مما سبق يتضح أن الدراسة ركزت في عرضها للقبم السباسية على استخدام اللغــة

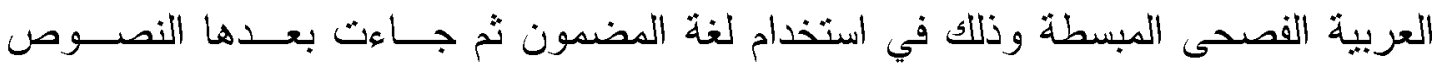

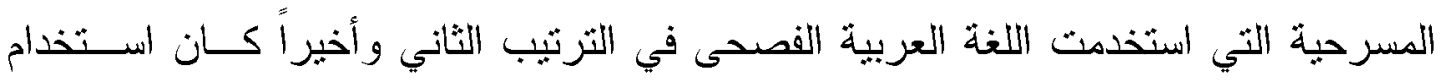

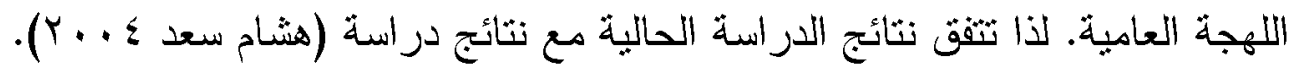




\section{جـــــــ (7)}

\section{نوع الشخصية التي صلدرت عنها القيه السياسية}

\begin{tabular}{|c|c|c|c|c|c|c|c|c|c|c|c|c|}
\hline \multicolumn{2}{|c|}{ الإجمالي } & \multicolumn{2}{|c|}{ أخرى تذكر } & \multicolumn{2}{|c|}{ جان } & \multicolumn{2}{|c|}{ عرائس } & \multicolumn{2}{|c|}{ طائر } & \multicolumn{2}{|c|}{ حيوان } & \multirow[t]{2}{*}{ نوع الشخصية } \\
\hline$\%$ & st & $\%$ & st & $\%$ & st & $\%$ & st & $\%$ & st & $\%$ & st & \\
\hline & $r \wedge$ & $\% r$ & 0 & - & - & $\% r$ & 1. & $\%, 7$ & $r$ & $\% r$ & 1. & العدل \\
\hline & rr & $\% \varepsilon$ & $r$ & - & - & $\%, r, \zeta$ & ir & $\% 1,7$ & & $\%, r, \zeta$ & ir & الانتماء \\
\hline & $r \xi$ & $\% \varepsilon$ & $r$ & - & - & $\% \cdot, 7$ & $r$ & $\% \bullet, \boldsymbol{\xi}$ & $r$ & $\% r, \xi$ & iv & الحرية \\
\hline & 7 & - & - & - & - & $\%, r$ & 1 & - & - & $\% 1$ & 0 & السلامر \\
\hline & ir & - & - & $\% \cdot r$ & 1 & $\%, \Lambda$ & $\xi$ & $\% \cdot, 7$ & $r$ & $\% 1$ & 0 & الشاركة \\
\hline & 1 & - & - & & & - & - & - & - & $\% r$ & 1 & المساواة \\
\hline & $r$ & - & - & - & - & - & - & - & - & $\% \bullet, 々$ & $r$ & المبادرة \\
\hline & - & - & - & - & - & - & - & - & - & - & - & الديمقراطية \\
\hline & 1.0 & & 9 & & 1 & & $r v$ & & 17 & & or & الإجمالي \\
\hline
\end{tabular}

ا- جاءت قيمة العدل لنظهر على لسان مجموعة من الثخصيات الحبو انية وعلـى لســان مجموعة من العر ائس بنسب تكرار مثساوية قدرها (Y\%) ثم على لسان مجموعة مـن الطيور بنسبة تكر ار (T, ، \%) و أخيراً على لسان شخصيات أخرى مختلفة بنسبة تكرار

ץ- ظهرت ثيمة الانتماء على لسان مجموعة من الحيو انات و العر ائس المختلفة بنسب نكرار

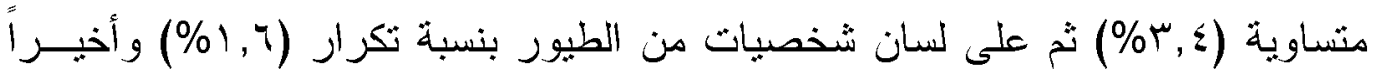

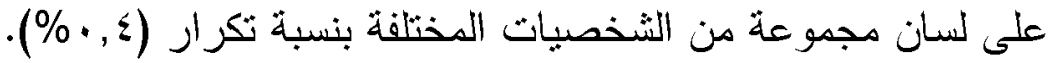
ب- ظهرث قيمة الحرية لتأني على لسان شخصيات حيو انية وبنسبة (ـ,r\%) ثم على لسان العر ائس بنسبة نكرار (T, • \%) و أخيراً يتساوى ظهور ها على لسان مجموعة من الطيور

$$
\text { والكائنات الأخرى بنسبة ثكرار (ع, • \%). }
$$

ـ- تأثي قيمة السلام على لسان مجموعة من الطيور بنسبة نكرار (1\%) ثم على لســـان مجموعة من العر ائس بنسبة نكرار (Y, •\%) ولم نظهر على لسان أبي شخصيات أخرى

$$
\text { خلال النص المسرحي. }
$$
ه- ظهرث قيمة المشاركة لتأتي على لسان مجموعة من الحيو انات بنسبة تكرار (1\%) ثـم على لسان مجموعة من العر ائس بنسبة تكرار (^, ، \%) و أخيراً على لسان مجموعة من

$$
\text { الطيور بنسبة (T, • \%). }
$$


ج- أما قيمة المساواة فاقتصر ظهور ها من خلال مجموعة من الثخصيات الحيو انبة بنسـبة نكرار (ץ, •\%) ولم تظهر على لسان أي شخصية أخرى. V- جاءت قيمة المبادرة و اقتصر ظهور ها على لسان مجموعة من الثخصبات الحبو انية فقط بنسبة نكرار (ع , •\%) ولم تظهر قيمة المبادرة على لسان أي شخصبة أخرى.

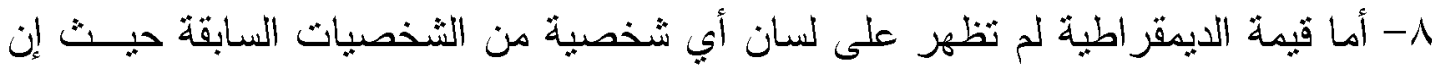

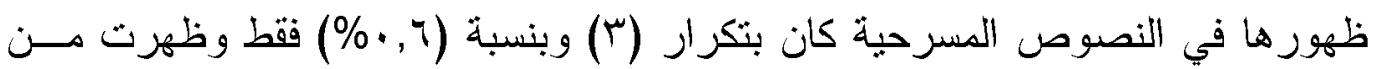
خلال الشخصيات البشرية فقط. مما سبق يتضح أن ظهور القيم السياسية في محملها كان مـن خـلال النصــوص المسرحبة على لسان مجموعة من الثُباب ثم على لسان مجموعة من الكبار ثم على لســان

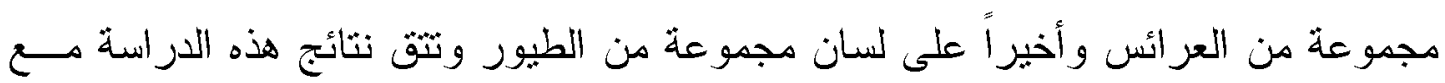

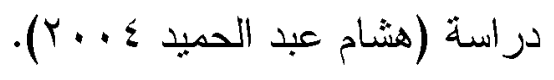

$$
\text { ج ( }
$$

\begin{tabular}{|c|c|c|c|c|c|c|c|c|}
\hline \multicolumn{2}{|c|}{ الإجمالي } & \multicolumn{4}{|c|}{ خارجي } & \multicolumn{2}{|c|}{ داخلي } & نوع| \\
\hline \multirow[b]{2}{*}{$\%$} & \multirow[b]{2}{*}{ ك } & \multicolumn{2}{|c|}{ بين أفراد المجتمع } & \multicolumn{2}{|c|}{ بين مجموعة من الأفراد } & \multicolumn{2}{|c|}{ بين رغبتيز داخل الفرد } & \\
\hline & & $\%$ & $s$ & $\%$ & $s$ & $\%$ & st & \\
\hline & & $\% \varepsilon, r$ & ri & $\% 11, q$ & vr & $\% r, \xi$ & A. & العدل \\
\hline & & $\%, r, r$ & $r$ & $\% 1,1$ & 70 & $\% 9,9$ & T\& & الانتماء \\
\hline & & $\% 1$, & $r$ & $\% A, \xi$ & o\& & $\% v$, & so & الحرية \\
\hline & & - & - & $\% 0,9$ & in & $\%, 9$ & is & السلاه \\
\hline & & $\% 1, \wedge$ & ir & $\% \varepsilon, r$ & rv & $\% r, \tau$ & iv & المشاركة \\
\hline & & - & - & $\%, r, \Lambda$ & IA & $\% r, r$ & 10 & المساواة \\
\hline & & - & - & $\% 1,\{$ & 9 & $\% 1, r$ & $\wedge$ & البادرة \\
\hline & & $\%,\{7$ & $r$ & $\%, q$ & 7 & $\% 1$, & $r$ & الديمقراطية \\
\hline & T\&Y & $\% 11, r$ & $n$ & $\% \varepsilon q, r$ & rar & $\%: r r, 7$ & rYz & الإجمائي \\
\hline
\end{tabular}

نوع الصراع المستخدم في عرض القيم السياسية 


$$
\text { بنضح من خلال الجدول السابق ما بلي: }
$$

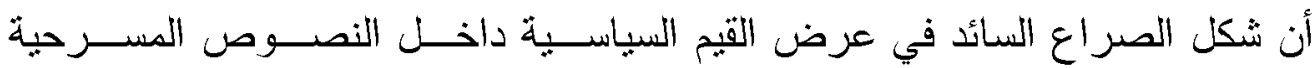

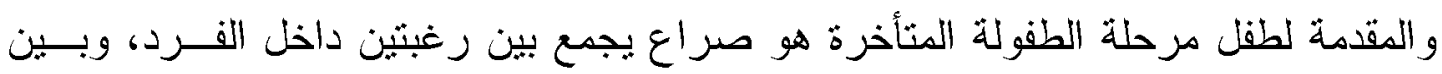
مجمو عة أفراد و هذا أقرب إلى الطفل في هذه المرحلة المقلة العمرية.

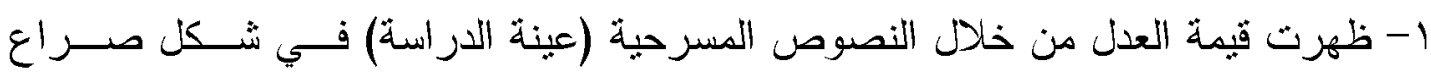

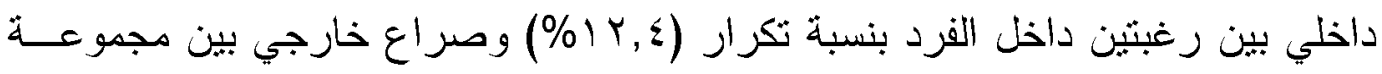

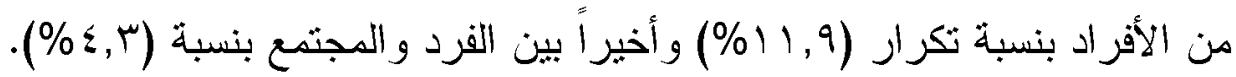

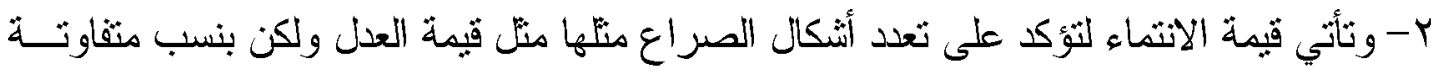

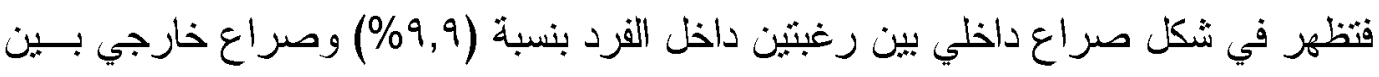

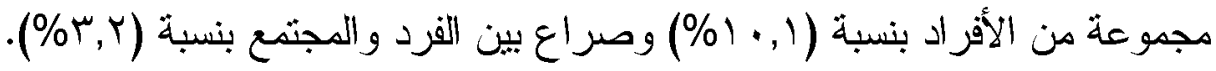

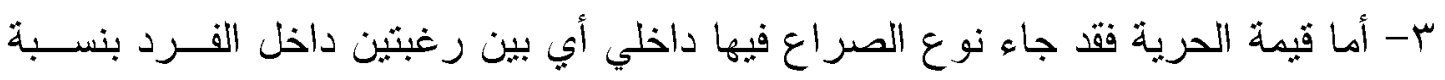

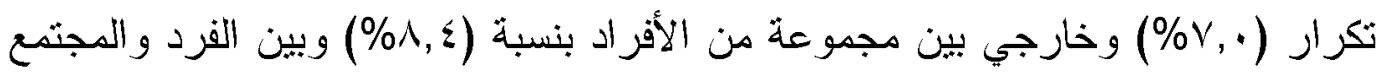

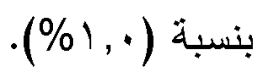

ـ- ويظهر نوع الصراع في قيمة السلام في شكل صراع داخلي بين رغبتين داخل الفــرد

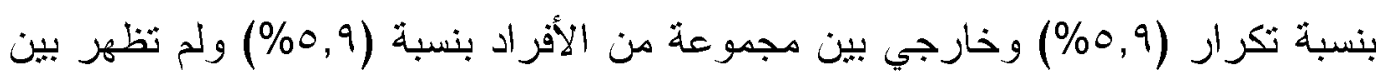

$$
\text { الفرد و المجتمع بأب بنسبة }
$$

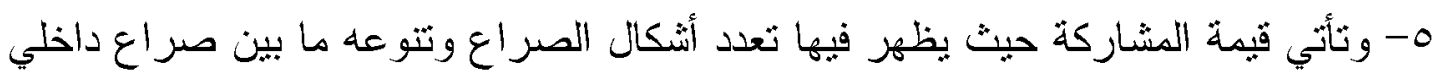

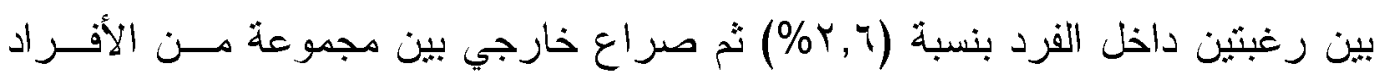

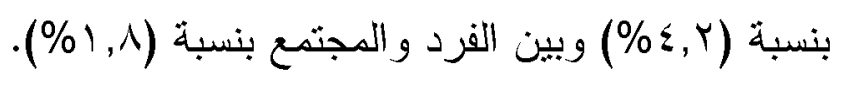

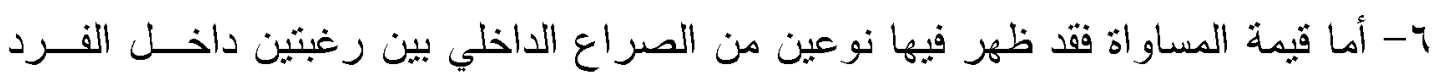

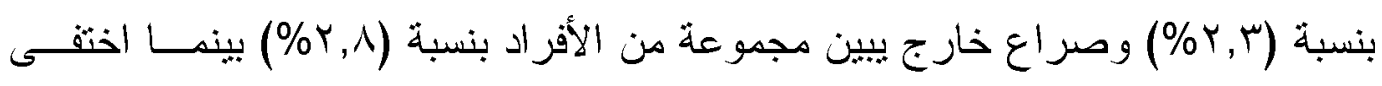

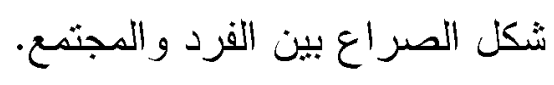

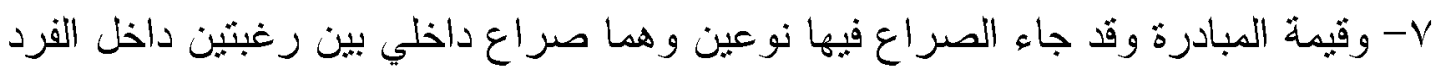

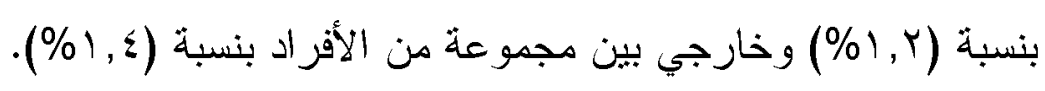

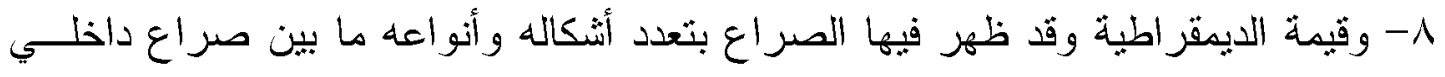

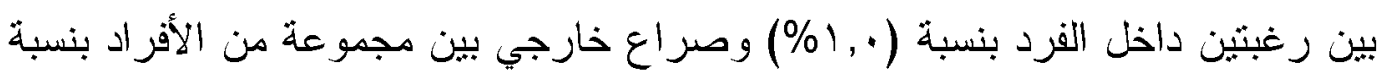

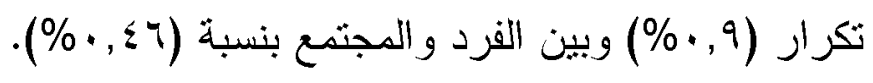


وتجد الدراسة أن ظهور القبم السياسية في مضمون النصوص المسرحبة في شــكل

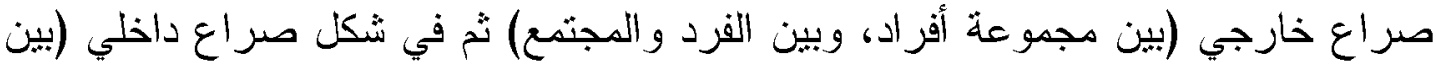

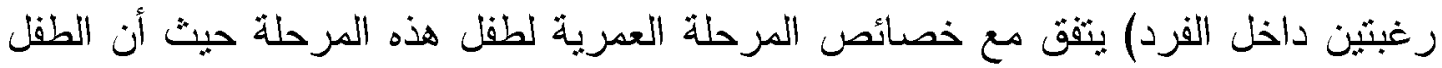

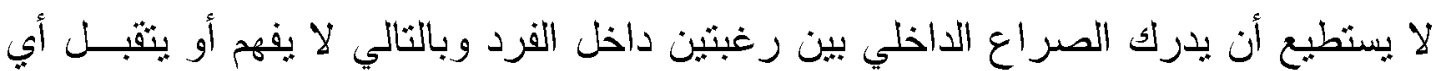

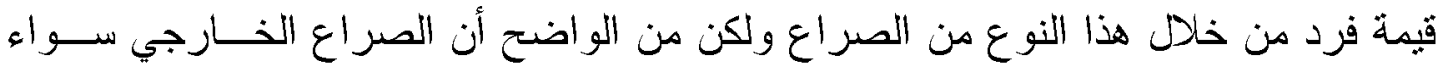

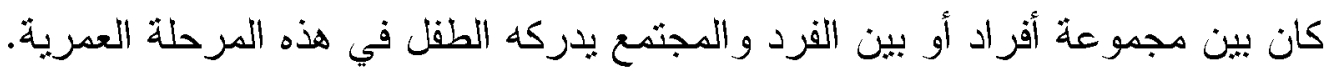

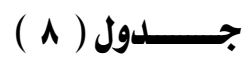

أسلوب حل الصراع الدرامي المستخدم في عرض القيم السياسية

\begin{tabular}{|c|c|c|c|c|c|c|c|c|c|c|}
\hline \multicolumn{6}{|c|}{ نوعه } & \multicolumn{4}{|c|}{ طبيعته } & \\
\hline \multicolumn{2}{|c|}{ التظاهر } & \multicolumn{2}{|c|}{ استخدام العنف } & \multicolumn{2}{|c|}{ سلمي } & \multicolumn{2}{|c|}{ جماعي } & \multicolumn{2}{|c|}{ فردي } & \\
\hline$\%$ & t5 & $\%$ & st & $\%$ & st & $\%$ & st & $\%$ & st & \\
\hline$\% \wedge$ & $\xi$ & $\% \mathfrak{\imath}, \wedge$ & rE & $\% 11, r$ & 07 & $\% \backslash \Lambda, \&$ & $a r$ & $\% 0,7$ & $r \wedge$ & العدل \\
\hline$\% r, r$ & 17 & $\% 9,7$ & $\{\Lambda$ & $\% \vee, r$ & ry & $\% 1 \varepsilon, \varepsilon$ & vr & $\% 0,7$ & $r \wedge$ & الانتماء \\
\hline$\% r, 7$ & ir & $\% V, r$ & ry & $\% \xi, r$ & rI & $\% \wedge$ & ६. & $\%$ & r. & الحرية \\
\hline$\% \varepsilon, r$ & HI & $\% r, \Lambda$ & 19 & $\% \Delta, r$ & ry & $\% 1 r, r$ & 97 & - & - & السلام \\
\hline- & - & $\% 0,1$ & $r q$ & $\% 7,7$ & rr & $\% 1 r, \varepsilon$ & ar & - & - & الشاركة \\
\hline- & - & $\% §, \wedge$ & rE & $\% 0, r$ & $r q$ & $\% 1$ & 0. & - & - & المساواة \\
\hline- & - & $\% r, \xi$ & ir & $\% r, \Lambda$ & 18 & $\% r$ & 10 & $\% r, r$ & 11 & المبادرة \\
\hline- & - & - & - & $\% \cdot, 7$ & $r$ & $\%, 7$ & $r$ & $\% \bullet, 7$ & $r$ & الديمقراطية \\
\hline$\% 1 \wedge, 7$ & & $\%$ \% , ₹ & $19 r$ & $\% \Sigma r$ & rio & $\% \wedge$ & \&०• & $\% r$ & $\% 1$ & الإجمالي \\
\hline
\end{tabular}

يتضح من خلال تحليل بيانات الجدول (

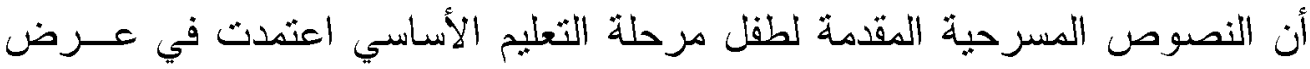

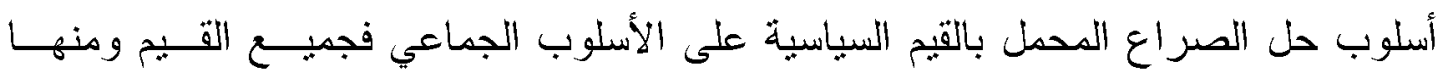

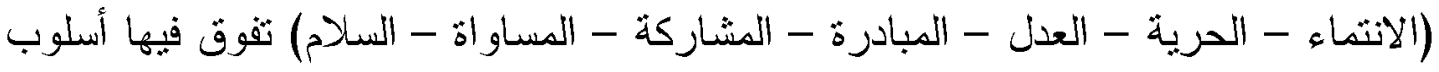

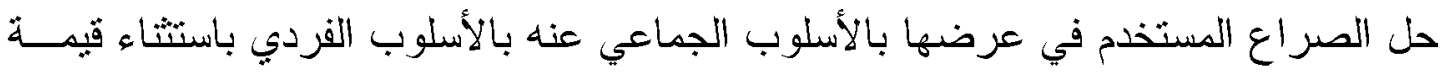

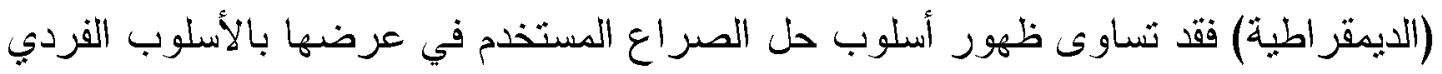

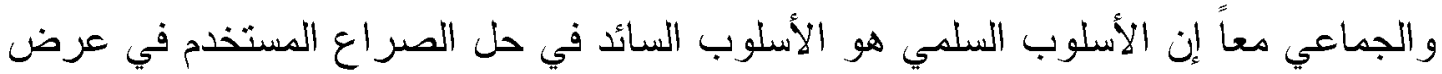

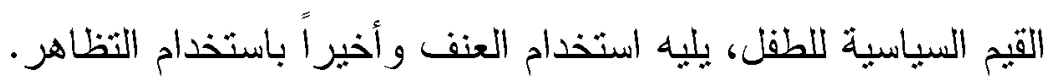


1- فقيمة العدل جاءت في النصوص المسرحبة لنظهر أسلوب حل الصر اع المستخدم فيهـا

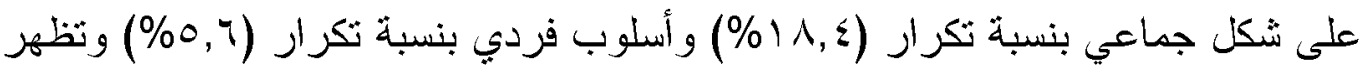

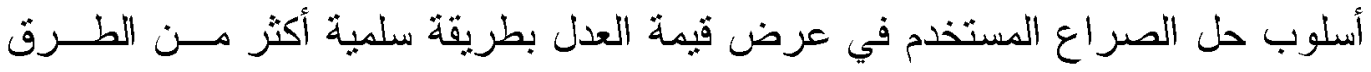

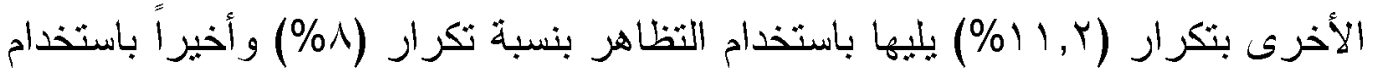

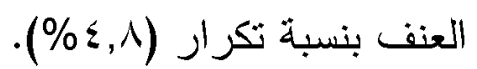

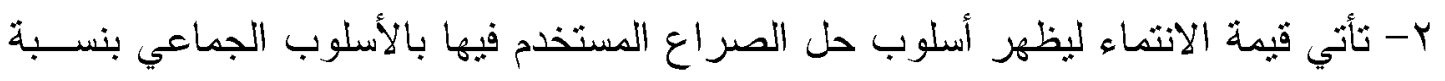

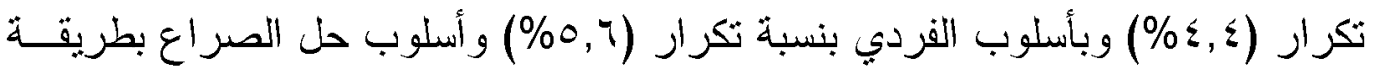

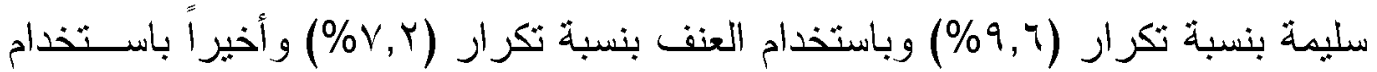
التظاهر بنسبة نكرار (r, (ب\%).

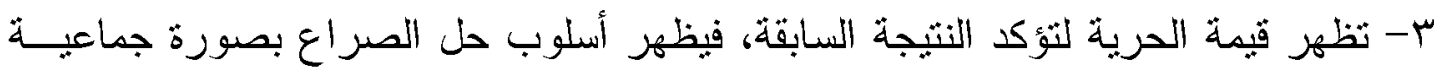

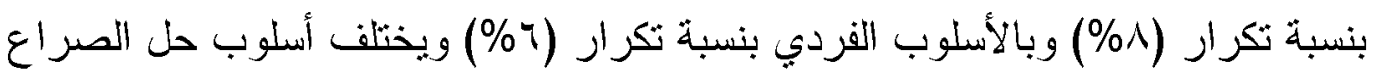

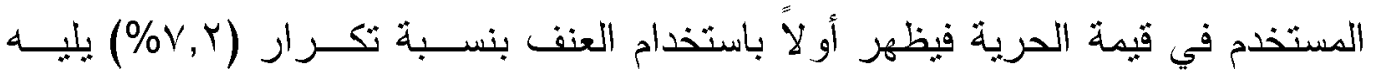

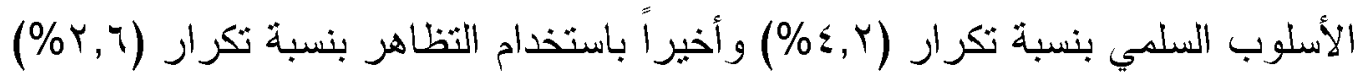

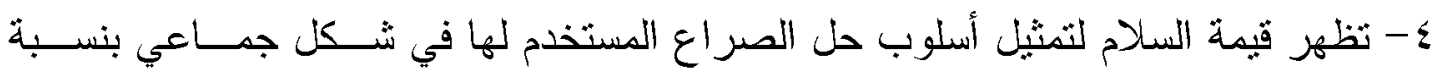

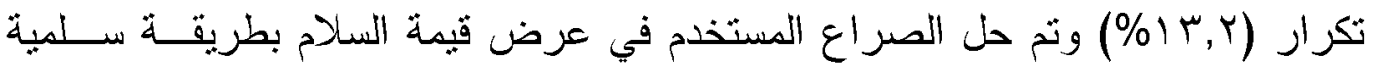

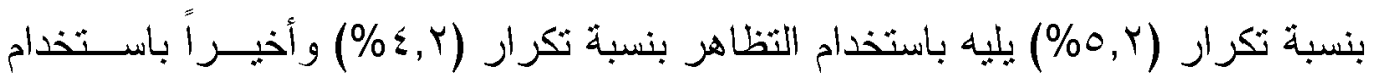

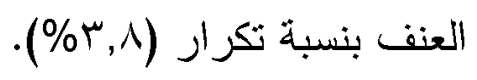

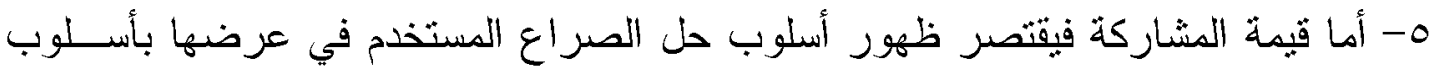

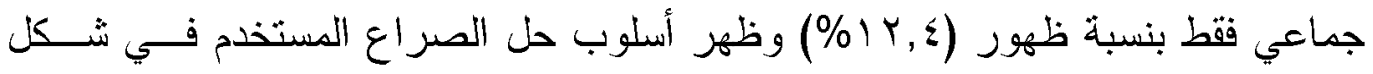

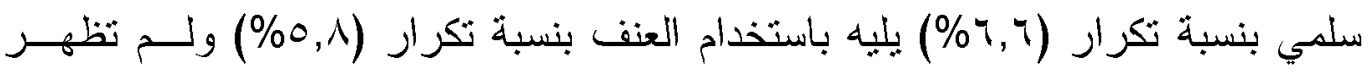
باستخدام النظاهر في أب نص من النصوص المسرحية.

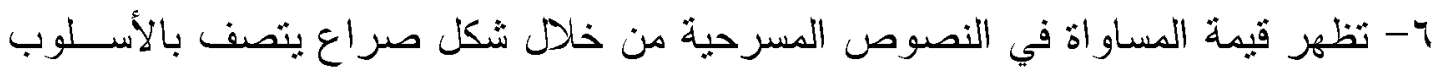
الجماعي فقط ولم بظهر في شكل فردي. فظهرث بشكل جماعي بنسبة تكـرار (· (1\%)

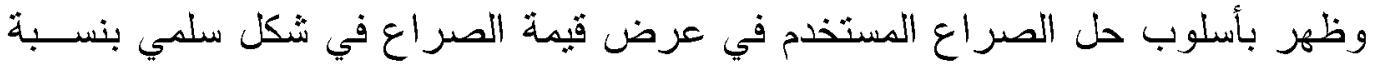

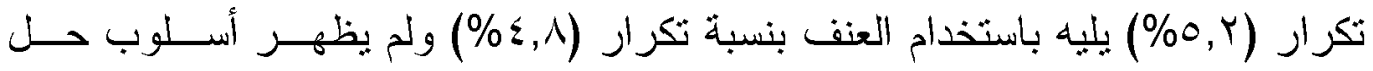
الصر اع المستخدم في عرض قيمة المساو اة باستخدام التظاهر .

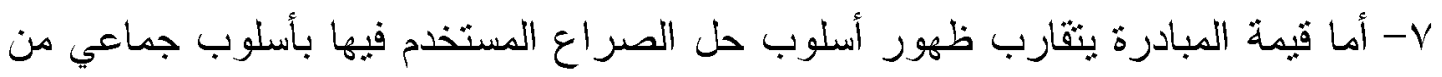

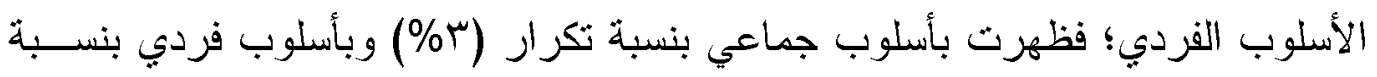


تكرار (Y,Y\%) ويظهز أسلوب حل الصراع المستخدم في عرض هذه القيمة في شـــل

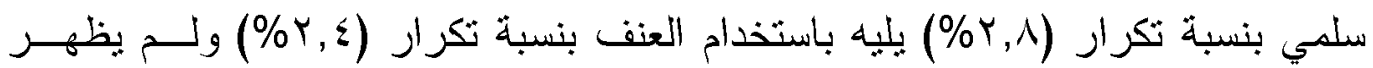
أسلوب الصراع المستخدم في عرض قيمة المبادرة باستخدام النظاهر إطلاقاً.

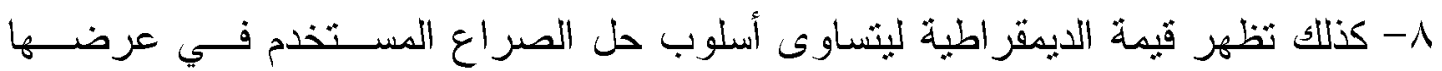

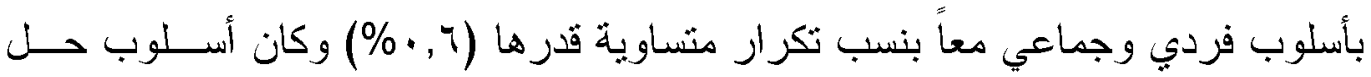

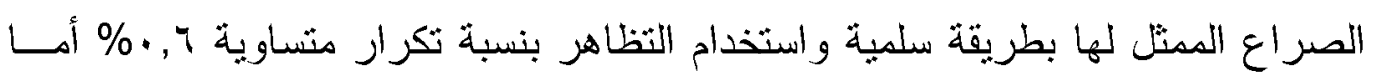
من حيث أسلوب حل الصراع المستخدم في عرض القيم فأظهرث نتائج الدراسة أن القبم

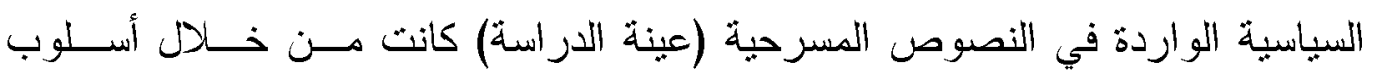

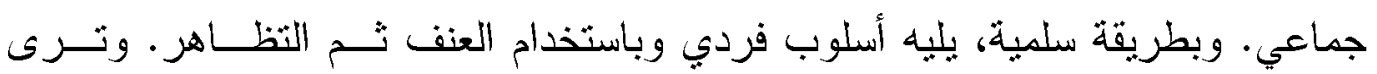

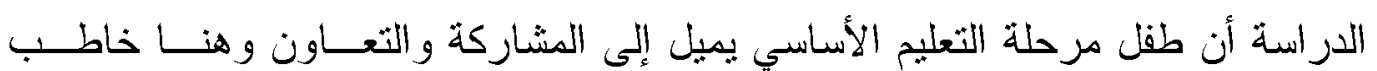

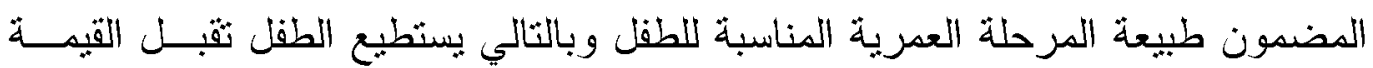
السياسبة المعروضة ويفهم أن أسلوب الحل يأني بطريقة جماعية تعاونية.

\section{مدى الاستفادة من إجراء هذه الدراسة:}

ا-نتاولت الدراسة العديد من القيم السياسبة التي تهم ثلاميذ مرحلة الطفولة المتأخرة من

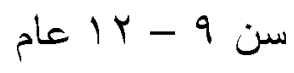

r-طرحت الدراسة عدة نوصيات ومقترحات ثوجه على القائمين على إعداد النصوص

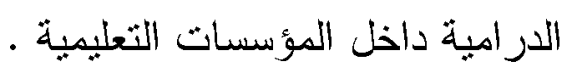

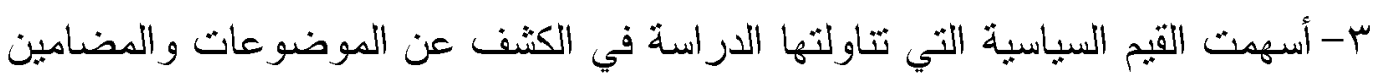
التي تقدم داخل نشاط المسرح المدرس في المؤسسات التعليمية .

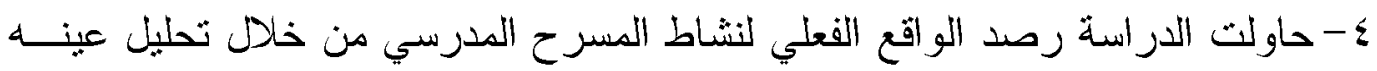
من النصوص المسرحية المدرسية التي عرضت في المهرجان الختامي وعلى خشبة التهبة

$$
\text { المسرح المدرسي في إقليم القاهرة الكبرى (القاهرة - الجيزة - القليو بية ). }
$$

0- كثفت نتائج الدراسة عن تفضبلات التناميذ في مرحلة الطفولة المتأخرة لنوعبة القيم

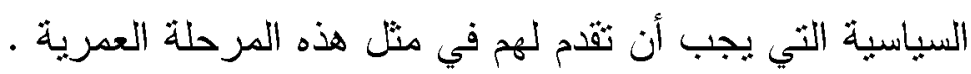
ج-و اكب الدراسة التغيرات والأحداث المجتمعية وخاصة السياسية التي أعقبت انبثــاق

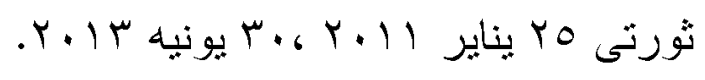




\section{النتائسج العامسة للدراسـة}

1- وجود بعض القيم السياسية المناسبة لطفل درحلة التعليم الأساسي بنسب عالية مما يؤكد على حرص المؤلف الدرامي و اهنمامه على غرس القبم السياسبة وتأكـــها فــي الــنص

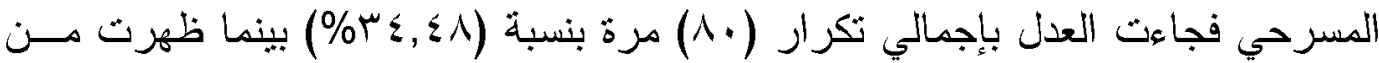
خلال التحليل الكمي بتكرار (.0) بنسبة (1,0\%) ومن خلال التحليل الكبفي (.r) مرة

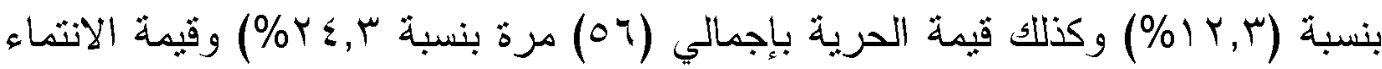

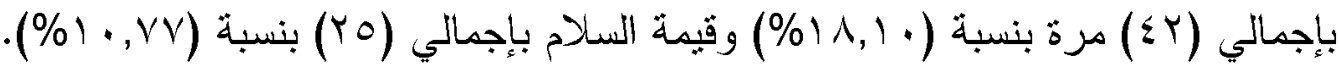
ب- ظهرت القيم السياسية في النصوص المسرحية (عينة الدراسة) من خلال الحــوار بــين

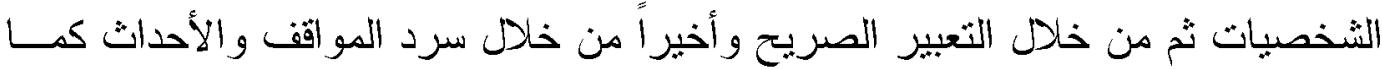
ظهر موقف المؤلف تجاه هذه القيم (بالمحايدة) فمعظم القــبم الـــواردة فــي النصـــوص المسرحية (عينة الدراسة) لم ثجد الدراسة أبي إثـارة لموقف المؤلف تجاهه ثم بدا ظهــور موقف المؤلف تجاه البعض الآخر هن القيم بروح التأيبد لها، ولكن لم يظهــر للهــؤلفين روح المعارض لأبي قيمة واردة في التحليل.

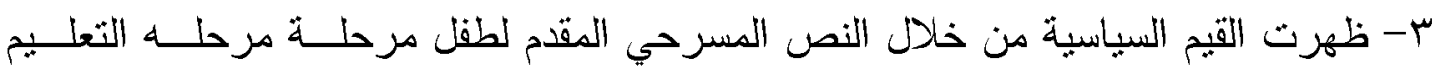
الأساسي من خلال اللغة العربية (الفصحى المبسطة) تليها مــن خـلال اللغــة العربيــة (الفصحى) و أخيراً عن طريث شخصيات ثتحدث اللهجة العامية. ـ - ظهرث القيم السياسية في النصوص المسرحية المقدمة لطفل مرحله التعليم الأساسي في شكل صراع خارجي بين مجموعة من الأفراد ثم في شكل صراع خارجي مـن الفـرد و المجثمع وأخيراً في شكل صراع داخلي (بين رغبتين داخل الفرد) وكان أســلـوب حـلـ الصراع يتسم بالتعاون فظهر في شكل جماعي ثم فردي وكان بطريقة سلمية ثم باستخدام

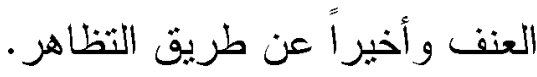




\section{قائمســة المراجـــ}

المصــادر:

1- مسرحية صرخة العصافير - تأليف إيمان فـــاروق إدارة شــبين القتـــر - محافظـــة

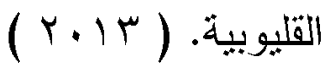

Y- مسرحية سلطان آخر الزمان: تأليف محمد عايش، إدارة العمرانية - محافظة الجيـزة.

$$
(r \cdot I \Sigma)
$$

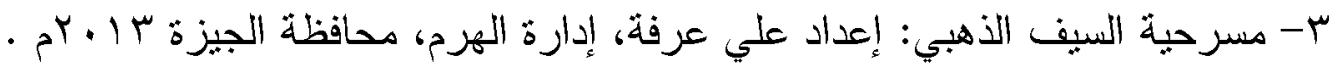

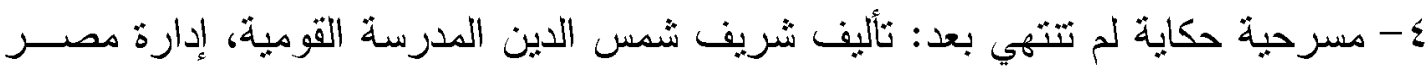

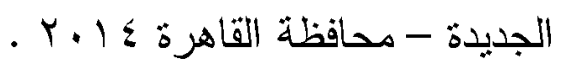

ه- مسرحية كلنا عايزين صورة: إعداد محمد سلطان، إدارة السيدة زينب، محافظة القــاهرة

$$
r \cdot 1 r \text {, }
$$

צ- مسرحية أبو خريبة على التل نأليف محد حسن سليمان مدرسة رياض الصالحين إدارة

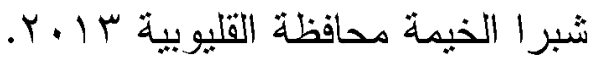

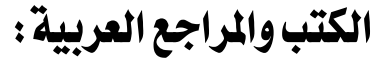

1- إلهام عبد الحمبد فرج : اتجاهات الطلاب، ثقافة المواطنة في مصر، القـاهرة، مركــز

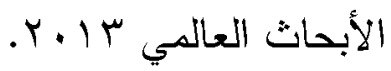

r- كمال الدين حسين: ملاحظات حول المسرح النعليمي، القاهرة، مطبعة العمر انية ه. . Y.

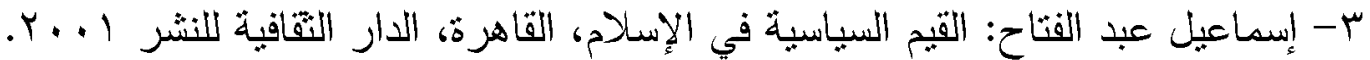

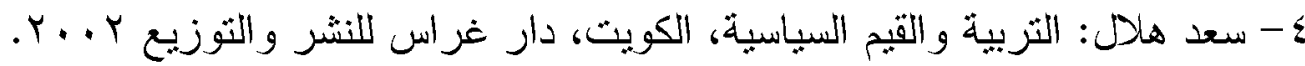

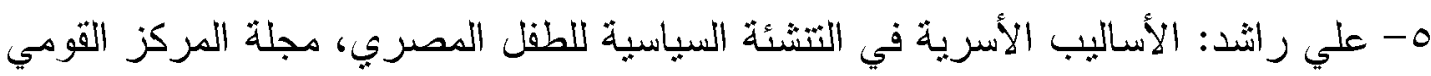

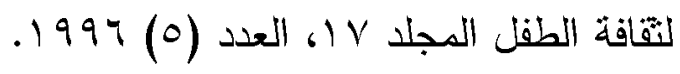

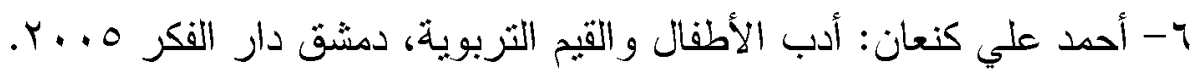

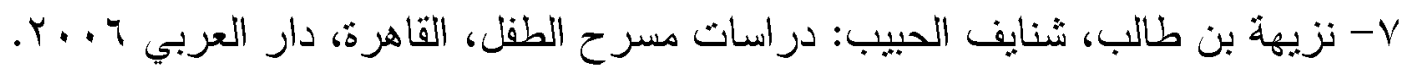

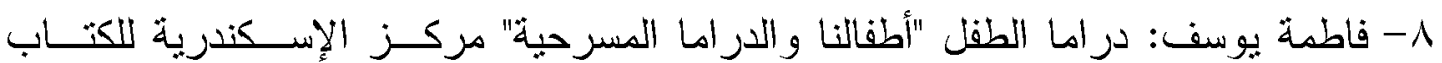
.r...

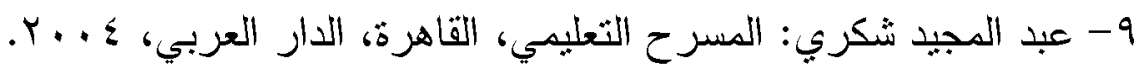




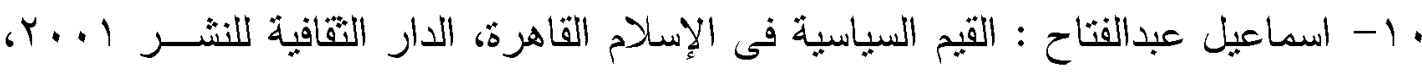
1.0

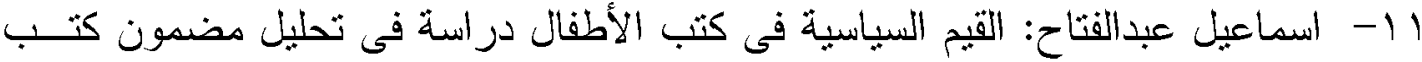

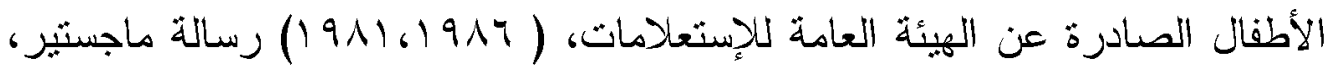

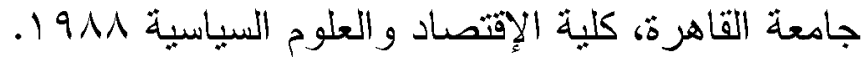

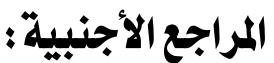

1- Halm, Ulla: The EU,s Seculity Tawards the mediterramean: Dlls warhing papar. 2004.

2- Casting, N.: Maze School Drama nraductiond emhrace, cummiaulum mewieu val (44) qssue (2), 2004.

3- Garuain mathe: How dojumiozhigh students mache values decisiam through pracess drama? M.E.D university of A ilurta, Comada.

4- Sylira carall: Fradom's children fifth graders perceptions of the effects of peace education in the form of kingian nonuialance, P.H.P university of A hode qsland 2005.

5- Huairy- Lyn: Thame of peyudice in selected play, from A merican theatro P.H.P. New your university 2005.

6- Betyien A ngela: Creating political theatre for young Audiences: A play and Accompaying Fxegesio queensland university of technlagy 2007.

7- Faulez chazles: Currant qssuesin crildren Drama for the $21^{\text {st }}$ century

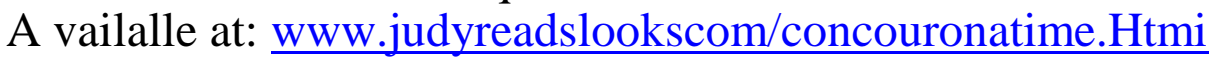

8- King leslay: Drama in schools: drama Enrichment pragromme To A cquire A waremen with contemporary qssues A rto coumcil, England. 2010.

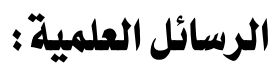

1- رمضان عبد الباري الوكيل: دور المسرح الدرسي في تتمية الانتماء للوطن، رسالة

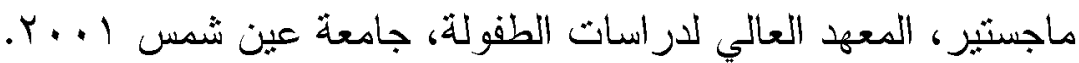

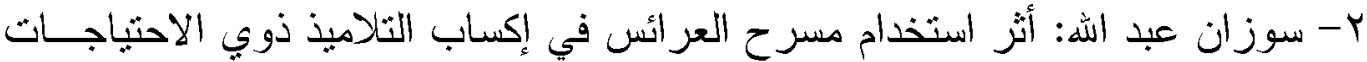

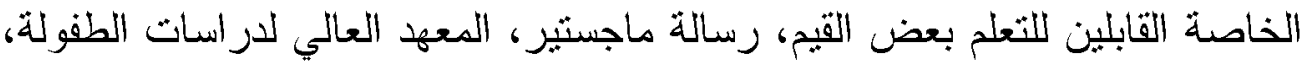

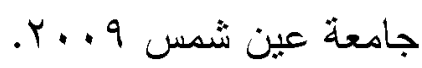




\section{The summary of study}

\section{Prohlem of the study:}

The problem of the study is clear in the fallceuing main question what are the palititcal values inualued same theatrieal texts presmtedin school theatre the aims of study.

The study aims to ansmar th following of questionas :

1- what are the political values suiralile to the children age firam 9 to 12 years .

2- what are the charocteras of child theatro and what are elements of its dramatic structwo.

3- What are the charactess of the child dramatist and what are the charactess of play praronted to thin child2.

4- What are the political values inualued the theatrical texts is sample of the studs presented from the shool pheare .

\section{Aprlied q mrartamce}

The applied impatance of the studs in dueto its concusions, Tde list of political values imualned in theatrical texts.

\section{Methcdolegy of the study:}

The study applies thedencrintine approach and content analy in syrtem to A nalysis the theatrical texts presonted to the child of the liasic education stage in ardes to mealise the political values somple thin study imccelues .

\section{Conclusioms of the study:}

1- the palitid values in theatrical texts are jurtice, lelonging freedam reace - cooremation- equalitiy imitatine and democracyrespectinely.

2- mast of the political political values mentioned in the theatmicd texts presomted to the child of lusic education stage are said by agroup of male yauth as by secamdazy charactes. Political values are rerarely mentioned by main characters. 